\title{
PERBELANJAAN AWAM DAN PERTUMBUHAN EKONOMI: BUKTI EMPIRIK DARIPADA KERAJAAN NEGERI DI SEMENANJUNG MALAYSIA
}

\author{
PUBLIC SPENDING AND ECONOMIC GROWTH: \\ AN EMPIRICAL EVIDENCE FROM STATE \\ GOVERNMENT IN PENINSULAR MALAYSIA
}

\author{
NORAIN MOD ASRI \\ ZULKEFLY ABDUL KARIM \\ MD ZYADI MD TAHIR \\ WOOK ENDUT \\ Fakulti Ekonomi dan Pengurusan \\ Universiti Kebangsaan Malaysia
}

\begin{abstract}
Abstrak
Kertas ini bertujuan mengkaji hubungan antara perbelanjaan awam dengan pertumbuhan ekonomi di peringkat kerajaan negeri di Semenanjung Malaysia. Beberapa pemboleh ubah yang lain seperti hasil cukai, imbangan fiskal, dan jumlah populasi penduduk juga diambil kira dalam menganggar model persamaan. Kajian ini mengaplikasi ujian kointegrasi Johansen untuk menganalisis hubungan jangka panjang (kointegrasi) dan model vektor pembetulan ralat (VECM) untuk menentukan arah sebab-menyebab dalam jangka pendek dan jangka panjang dalam kalangan pemboleh ubah kajian. Keputusan kajian menunjukkan; pertama, tidak wujud hubungan jangka panjang antara output negeri dengan belanja awam di negeri Selangor. Kedua, di negeri Pahang dan Melaka wujud hubungan sebab-menyebab dua hala dalam jangka panjang antara output negeri dengan belanja awam. Ketiga, dalam jangka pendek, perubahan output signifikan menjadi penyebab Granger kepada perubahan perbelanjaan awam di Negeri Sembilan, Kedah, Melaka dan Pulau Pinang, yang menyokong hipotesis Wagner. Sebaliknya, di negeri Pahang dan Perak, perubahan perbelanjaan awam signifikan menjadi penyebab Granger kepada perubahan output dalam jangka pendek, yang mengesahkan hipotesis Keynes di negeri tersebut.
\end{abstract}

Kata kunci: Perbelanjaan awam, pertumbuhan ekonomi, ujian kointegrasi Johansen, VECM, VAR. 


\begin{abstract}
Purpose - This paper investigates the relationship between public spending and economic growth using the state level data in Peninsular Malaysia. Several other variables namely tax revenue, fiscal balance, and total population have also been considered in estimating the baseline model.

Design/methodology/approach - This study applied the Johansen cointegration test in analyzing the long run relationship (cointegration) among the variables of interest, and a vector error correction model (VECM) in investigating the direction of causality in the long-run and short run among the variables.
\end{abstract}

Findings - The empirical findings can be summarized as follows. First, there is no long-run relationship among state output and public spending in Selangor. Second, in Pahang and Melaka, there is a long run bi-directional causality between state output and public spending. Third, in the short run, a changes in output is significantly to Granger cause the public spending in Negeri Sembilan, Kedah, Melaka and Pulau Pinang, in which has supported the Wagner hypothesis. In contrast, in Pahang and Perak, a changes in public spending has a significance effect to Granger cause the changes of output in the short run, in which has confirmed the existence of Keynesian hypothesis in those states.

Originality/value - This study provides new empirical evidence on the relationship between public spending and economic growth using the state level data in Peninsular Malaysia. Moreover, several other variables namely tax revenue, fiscal balance, and state population have also been considered in the baseline model.

Keywords - public spending, economic growth, Johansen cointegration test, VECM, VAR.

Paper type - Research Paper.

\title{
Pengenalan
}

Episod turun naik dalam kitaran ekonomi sering kali menuntut pelarasan dasar fiskal agar kesan daripada ketakstabilan ekonomi tersebut tidak berpanjangan. Dalam hal ini, mekanisme pelarasan yang kerap dipraktiskan lebih tertumpu kepada pemboleh ubah perbelanjaan awam apabila dapat mempengaruhi pertumbuhan 
ekonomi secara langsung berbanding dengan komponen fiskal yang lain. Namun begitu, perbelanjaan awam ini sebenarnya boleh mengundang kepada kewujudan kesan asakan keluar (crowding-out effects). Hal ini bererti peningkatan perbelanjaan awam melalui dasar belanjawan defisit akan meningkatkan kadar bunga domestik yang seterusnya akan mengurangkan pelaburan daripada sektor swasta. Akibatnya, sesebuah negara akan mengalami kesukaran untuk mencapai suatu laluan pertumbuhan yang seimbang (balance growth path) dalam jangka panjang (Raurich, 2001).

Walaupun begitu, kajian mengenai hubungan antara perbelanjaan awam dengan output masih lagi relevan sehingga ke hari ini kerana kegawatan ekonomi (termasuk pada zaman kemelesetan besar atau Great Depression pada tahun 1930-an) telah terbukti dapat distabilkan menerusi campur tangan yang aktif daripada sektor awam. Berdasarkan kajian terdahulu, terdapat dua pendekatan yang telah digunakan untuk melihat hubungan antara belanja awam dengan output (pendapatan) negara (Wahab, 2004). Pertama, perbelanjaan kerajaan dianggap sebagai pemboleh ubah endogenous seperti yang dikemukakan oleh Wagner (1958). Hal ini bermaksud perubahan perbelanjaan awam dipengaruh oleh perubahan pendapatan negara secara anjal, iaitu kadar (peratusan) peningkatan perbelanjaan awam melebihi daripada kadar peningkatan output negara. Hukum Wagner ini dianggap oleh Akitoby, Clements, Gupta, dan Inchauste (2006) sebagai 'voracity effect' yang berlaku disebabkan beberapa faktor seperti kelemahan institusi dan perpecahan etnik. Ia dimanifestasikan menerusi kemunculan pelbagai kumpulan berkepentingan yang meminta lebih peruntukan perbelanjaan awam bagi melindungi kebajikan mereka dalam pembangunan negara.

Walau bagaimanapun, analisis Wagner agak terbatas pada masa ekonomi gawat. Beliau tidak melihat secara jelas kesan kegawatan ekonomi (kejatuhan output negara) terhadap pertumbuhan perbelanjaan awam. Realitinya, terdapat tiga bentuk tindak balas belanja awam terhadap kejatuhan pendapatan negara. Pertama, sekiranya kemerosotan output negara menyebabkan peningkatan dalam belanja awam, maka ini mencerminkan belanja awam bertindak sebagai 'countercyclical instrument' untuk merangsang kembali pertumbuhan ekonomi. Kedua, jika kejatuhan (peningkatan) output diiringi dengan kejatuhan (peningkatan) belanja awam pada kadar yang lebih tinggi (rendah), maka bentuk hubungan ini menyangkal hukum Wagner. Ketiga, jika kejatuhan (peningkatan) output diiringi dengan kejatuhan (peningkatan) belanja awam pada 
kadar yang lebih rendah (tinggi), lantas hubungan ini dikatakan konsisten dengan hukum Wagner dan turut merujuk kepada 'cyclical ratcheting' (Akitoby et al., 2006).

Pendekatan yang kedua melihat perbelanjaan awam sebagai pemboleh ubah eksogenous menurut jurus pandang ahli ekonomi Keynesian. Hal ini bererti peningkatan perbelanjaan awam akan merangsang peningkatan pendapatan negara melalui pemboleh ubah perbelanjaan agregat. Sebagai contoh, campur tangan kerajaan menerusi peruntukan terhadap perbelanjaan awam dan cukai bersih (iaitu cukai kasar ditolak bayaran pindahan) memberikan kesan yang berbeza terhadap perbelanjaan agregat. Kesan pertambahan perbelanjaan awam terhadap pertumbuhan ekonomi sebenarnya adalah lebih besar berbanding dengan kesan kejatuhan cukai bersih kerana saiz pengganda perbelanjaan awam yang lebih besar berbanding dengan pengganda cukai. Namun begitu, sekiranya kadar pertambahan perbelanjaan awam kurang daripada kadar pertambahan pungutan cukai, maka tabungan awam akan meningkat. Sebaliknya, pertambahan cukai pula bakal mengundang kejatuhan dalam tabungan swasta, yang mana akan menjejaskan paras tabungan negara, dan akhirnya menjejaskan aktiviti pengumpulan modal dan kegiatan ekonomi.

Memandangkan terdapat banyak kemungkinan berkaitan arah hubungan antara perbelanjaan awam dengan output, maka kajian ini mendalami isu tersebut bagi kes kerajaan negeri di Semenanjung Malaysia. Kajian ini memberikan sumbangan yang signifikan terhadap bidang ekonomi fiskal daripada beberapa aspek. Pertama, kajian ini menggunakan data di peringkat kerajaan negeri dengan menggunakan data ekonomi bersaiz kecil (Malaysia). Banyak kajian lepas hanya memberikan fokus kajian menurut perspektif negara besar (maju) khususnya negara Amerika Syarikat (AS) seperti yang dilakukan oleh Kolluri, Panik dan Wahab (2000), Folster dan Henrekson (2001), Wahab (2004), dan Glass (2009). Maka, dengan menggunakan data pada peringkat kerajaan negeri, dapat memberikan maklumat kepada penggubal dasar di negeri yang berkenaan untuk melaksanakan dasar belanjawan yang lebih berhemah dan cermat, iaitu dengan mengambil kira kedudukan ekonomi sebelum memutuskan sesuatu dasar belanjawan yang hendak dilaksanakan. Kedua, kajian ini juga mengambil kira beberapa pemboleh ubah lain yang penting seperti hasil cukai, imbangan fiskal dan jumlah populasi dalam model penganggaran. Hal ini kerana kitaran perbelanjaan awam dan output pada peringkat kerajaan negeri amat bergantung kepada perubahan hasil cukai, imbangan fiskal dan jumlah populasi. 
Penemuan penting kajian ini pula diringkaskan kepada tiga aspek. Pertama, tidak wujud hubungan jangka panjang antara output negeri dengan belanja awam bagi kerajaan negeri Selangor. Kedua, di Pahang dan Melaka wujud hubungan dua hala dalam jangka panjang antara output negeri dengan belanja awam. Ketiga, dalam jangka pendek, wujud hipotesis Wagner di Negeri Sembilan, Kedah, Melaka dan Pulau Pinang, manakala, dalam jangka pendek hipotesis Keynes wujud di Pahang dan Perak.

Kertas ini dibahagikan kepada beberapa bahagian. Bahagian kedua membincangkan secara ringkas latar belakang hipotesis Keynesian dan hipotesis Wagner mengenai hubungan antara perbelanjaan dengan pertumbuhan ekonomi. Bahagian ketiga meninjau daripada aspek soroton kajian lepas yang melihat hubungan antara perbelanjaan dengan pertumbuhan ekonomi. Bahagian keempat menerangkan metodologi kajian dengan tumpuan kepada model vektor pembetulan ralat (VECM). Bahagian kelima mempersembahkan hasil kajian, manakala bahagian keenam meringkas dan merumuskan hasil kajian.

\section{Hipotesis Keynes dan Hipotesis Wagner}

Secara teori, terdapat dua hipotesis yang mendasari hubungan antara perbelanjaan kerajaan dengan output. Hipotesis pertama, iaitu pandangan ahli ekonomi Keynesian yang melihat pengaruh perbelanjaan kerajaan (khususnya melalui belanjawan defisit) terhadap pertumbuhan ekonomi negara. Keynesian berpandangan campur tangan yang aktif daripada kerajaan melalui dasar-dasar pengurusan permintaan agregat adalah penting untuk menstabilkan ekonomi negara (pertumbuhan ekonomi). Di samping itu, dasar fiskal yang proaktif menerusi perbelanjaan awam ini juga merupakan instrumen penting yang menjana pertumbuhan ekonomi serta guna tenaga terutama sekali apabila sesebuah negara berada pada peringkat awal pertumbuhan (Al-Faris, 2002). Idea Keynesian ini juga selari dengan penambahbaikan terhadap teori pertumbuhan endogenous seperti yang dilakukan oleh Barro (1990) yang menekankan kesan langsung perbelanjaan awam yang produktif terhadap fungsi pengeluaran dan penggunaan swasta. Idea Barro (1990) ini telah disokong oleh Grossman dan Helpman (1991) serta Tanzi dan Zee (1996). Walaupun Barro (1991) kemudiannya gagal membuktikan kepentingan belanja awam terhadap output dengan menggunakan data di negara maju dan negara sedang membangun, tetapi beliau telah merumuskan bahawa saiz sektor awam (belanja awam) yang 
besar bakal membantut pertumbuhan ekonomi. Hal ini disebabkan oleh saiz belanja awam yang besar bakal disertai oleh defisit fiskal dan seterusnya cukai yang tinggi lantas ia akan melemahkan pertumbuhan ekonomi.

Hipotesis kedua pula dikemukakan oleh ahli ekonomi Jerman, Wagner (1958), yang menegaskan bahawa belanja awam merupakan pemboleh ubah endogenous yang ditentukan oleh pertumbuhan ekonomi. Beliau juga menyatakan belanja awam lebih bersifat anjal terhadap pertambahan pendapatan negara yang kebiasaannya koefisien keanjalan belanja awam terhadap pertumbuhan ekonomi melebihi daripada satu. Dalam kata lain, teori ini menjelaskan saiz pertumbuhan sektor awam lebih cepat daripada saiz pertumbuhan ekonomi. Terdapat tiga faktor yang telah dikenal pasti menyumbang kepada tindak balas perbelanjaan awam tersebut. Pertama, apabila ekonomi berkembang, maka wujud peningkatan keperluan dan permintaan terhadap barangan awam (keselamatan, pendidikan, dan infrastruktur) yang ditawarkan oleh kerajaan. Kedua, peningkatan peruntukan bagi barangan sosial dan budaya, dan ketiga, kawalan birokrasi serta pentadbiran yang baik bagi menjamin kelancaran operasi pasaran. Hukum Wagner ini telah berjaya dibuktikan oleh Kolluri, Panik dan Wahab(2000) dan Akitoby et al. (2006) bagi kes negara perindustrian maju dan negara membangun. Sebaliknya, Henrekson (1993) gagal mengesahkan kewujudan hukum Wagner manakala Wahab (2004) pula memperoleh keputusan yang bercampur iaitu beliau mendapati hipotesis Wagner wujud di negara Eropah tetapi tidak wujud di negara G7 dan Organisation for Economic Cooperation and Development (OECD).

\section{Kajian Lepas}

Hubungan antara perbelanjaan awam dengan pertumbuhan ekonomi telah pun dikaji dengan mendalam oleh ramai pengkaji sebelum ini seperti Aschauer (1989), Barro (1981, 1987), Evans dan Karras (1994), dan Henrekson (1993). Namun, disebabkan kaedah pengujian yang berbeza, maka keputusan yang diperoleh adalah pelbagai. Sebagai contoh, Rao (1989) berjaya mengesahkan hipotesis Wagner bagi keduadua kumpulan negara maju dan negara berpendapatan rendah serta sederhana. Al-Faris (2002) juga menyokong hipotesis Wagner bagi negara rantau Arab kecuali Bahrain yang menunjukkan kewujudan hubungan dua hala antara perbelanjaan awam dengan pertumbuhan ekonomi. Al-Faris (2002) turut menegaskan bahawa pertumbuhan 
output dan guna tenaga di dalam sektor bukan petroleum telah menarik ramai 'expatriate' yang turut membawa keluarga mereka ke negara Arab berkenaan. Hal ini seterusnya menyebabkan kerajaan negara Arab terpaksa menambah perbelanjaan dalam penyediaan infrastruktursertakhidmatsosial. Beliaujuga menggariskan tigaalasan yang menyebabkan perbelanjaan awam tidak mempengaruhi output seperti yang diketengahkan oleh Keynesian. Pertama, kerajaan lebih banyak memperuntukkan perbelanjaan awam terhadap komponen yang kurang produktif iaitu perbelanjaan semasa (mengurus). Kedua, sebarang penawaran barangan awam yang dilihat bersaing dengan sektor swasta akan mengarah kepada kejatuhan ekonomi. Ketiga, impak perbelanjaan sosial seperti perbelanjaan pendidikan, kesihatan serta infrastruktur terhadap pertumbuhan ekonomi akan mengambil masa.

Dapatan kajian Al-Faris (2002) di atas selari dengan keputusan Devarajan, Swaroop dan Zou (1996) yang membuktikan perbelanjaan modal (perbelanjaan produktif) berhubungan negatif atau tidak mempunyai hubungan dengan output disebabkan kerajaan memperuntukan perbelanjaan modal melebihi tahap optimum. Walaupun begitu, mereka berjaya mengesahkan kewujudan hipotesis Keynesian bagi hubungan perbelanjaan awam total dengan pertumbuhan output. Tetapi, peningkatan jumlah perbelanjaan awam ini hanya mampu mendorong peningkatan kutipan cukai dan kadar pertumbuhan output pada 'steady state' dengan syarat produktiviti perbelanjaan awam melebihi daripada kerugian luput (beban berlebihan) akibat peningkatan cukai tersebut. Sebaliknya, Folster dan Henrekson (2001) pula mendapati perbelanjaan awam mempengaruhi output secara negatif di negara maju (kaya). Hal ini terkesan daripada keupayaan perbelanjaan awam mengasak keluar pelaburan swasta dengan banyak yang menyebabkan kejatuhan outputnegara. Selainitu, banyak kajian terbaru pula dilihat mengambil kira kesan perbelanjaan awam secara simetri dan asimetri terhadap output negara. Contohnya, analisis keratan rentas oleh Wahab (2010) mendapati perbelanjaan awam hanya mempengaruhi output apabila pertumbuhan perbelanjaan awam berada di bawah 'trend growth' dengan menggunakan model asimetri, sedangkan model simetri menunjukkan output negara sememangnya dipengaruhi oleh perbelanjaan awam secara positif.

Di Malaysia, kajian mengenai hubungan antara perbelanjaan awam dengan pertumbuhan ekonomi tidak mendapat perhatian yang meluas daripada pengkaji lepas serta lebih tertumpu kepada 
persoalan hukum Wagner dengan menggunakan data di peringkat kerajaan persekutuan. Misalnya, Sinha (1998) mendapati kewujudan hipotesis Wagner pada Malaysia dalam jangka panjang. Selain itu, kajian beliau juga mendapati tidak wujud sebarang hubungan antara pertumbuhan ekonomi dengan perbelanjaan awam dalam jangka pendek, lantas beliau merumuskan faktor bukan ekonomi lebih dominan mempengaruhi perbelanjaan awam dan pertumbuhan output di Malaysia. Ghani, Habibullah, Azali dan Azman-Saini (2005) yang menggunakan pendekatan ARDL pula berjaya membuktikan kewujudan hubungan dua hala antara pertumbuhan ekonomi dan belanja awam dalam jangka panjang, manakala hukum Keynes hanya berlaku dalam jangka pendek. Sebaliknya, Norain, Md. Zyadi dan Wook (2010) yang menggunakan model vektor ralat pembetulan (VECM) telah mendapati hipotesis Keynesian wujud dalam jangka panjang, manakala dalam jangka pendek, hipotesis Wagner wujud sama ada dengan menggunakan data agregat atau subkomponen perbelanjaan awam. Kajian oleh Fatimah, Zarinah, Saad dan Ahmad Farid (2010) juga mengesahkan impak positif antara perbelanjaan pembangunan terhadap pertumbuhan ekonomi, yang mana kesan perbelanjaan awam ini lebih besar berbanding kesan pelaburan asing terhadap pertumbuhan output. Kajian pada peringkat kerajaan tempatan pula telah dilakukan oleh Dayang-Affizzah, Habibullah dan Azman-Saini (2006) serta Habibullah dan Dayang-Affizzah (2008) yang masing-masing bagi kes kerajaan tempatan di Sabah dan Sarawak. Mereka turut memperoleh keputusan yang pelbagai, iaitu hubungan sehala serta hubungan dua hala antara belanja awam dengan pertumbuhan ekonomi.

Berdasarkan tinjauan kajian lepas di atas, amat jelas terdapat beberapa jurang literatur yang belum diterokai lagi, khususnya bagi kes di Malaysia. Maka, kajian ini menerokai isu tersebut dengan memberikan sumbangan kepada dua inovasi penting dalam bidang ekonomi fiskal. Pertama, berbeza dengan kajian terdahulu di Malaysia yang menggunakan data pada peringkat kerajaan persekutuan, kajian ini mengkaji hubungan antara perbelanjaan awam dengan pertumbuhan ekonomi pada peringkat kerajaan negeri di Semenanjung Malaysia. Hal ini penting untuk mengenal pasti gelagat pembuat dasar di kerajaan negeri yang diandaikan lebih dekat serta memahami kehendak dan keperluan pengundi/pembayar cukai. Kedua, kajian ini juga mengambil kira beberapa pemboleh ubah lain seperti hasil cukai, imbangan fiskal, dan populasi negeri dalam model persamaan. Ini kerana kitaran perbelanjaan awam dan pertumbuhan ekonomi juga terdedah terhadap perubahan pemboleh ubah tersebut. 


\section{Spesifikasi Model dan Data}

\section{Spesifikasi Model}

Kajian ini menggunakan pendekatan Akitoby et al. (2006) yang mengaplikasi teori Wagner untuk menunjukkan hubungan keseimbangan (steady-state) antara belanja awam (G) dengan output atau Keluaran Dalam Negeri Kasar (Y). Secara ringkas, model tersebut adalah seperti berikut:

$$
G_{t}=A Y_{t}^{\delta}
$$

yang mana, menurut Wagner, $\delta>1$, dan $\delta$ juga merupakan nilai keanjalan konstan jangka panjang belanja awam terhadap output negara. Persamaan (1) di atas boleh ditulis semula dalam bentuk linear sebagai:

$$
G_{t}=a+\delta Y_{t}+\mu_{t}
$$

dengan $a=\log A$, dan $\mu$ adalah sebutan ralat rawak. Namun, bagi memperhalusi gelagat dan kitaran belanja awam tersebut, maka persamaan (2) di atas telah diubah suai dengan mengambil kira pergerakan dalam hasil dan imbangan fiskal seperti yang disarankan oleh Akitoby et al. (2006). Maka, dengan mengambil kira pemboleh ubah hasil cukai (HC) dan imbangan fiskal (IF) ke dalam persamaan (2), persamaan baru bolehlah ditulis seperti berikut:

$$
G_{t}=a+\delta Y_{t}+\beta H C_{t}+\alpha I F_{t}+\mu_{t}
$$

Persamaan (3) hanya memfokus kepada hasil cukai dan bukannya sumber hasil yang lain disebabkan hasil cukai, terutama sekali cukai tanah yang berkadar malar (flat-rate), merupakan antara hasil utama kerajaan negeri di Malaysia. Kutipan hasil cukai ini diandaikan digunakan sepenuhnya untuk membiayai perbelanjaan kerajaan negeri. Andaian ini juga dilihat hampir selari dengan idea Barro (1990) yang menegaskan belanja awam pada peringkat kerajaan persekutuan umumnya dibiayai oleh cukai pendapatan yang berkadar malar. Kemasukan pemboleh ubah imbangan fiskal pula membolehkan tindakan pengukuhan fiskal oleh sesebuah kerajaan negeri dikenal pasti menerusi perubahan kedudukan imbangan fiskal Dalam masa yang sama, daripada jurus pandang pembangunan ekonomi wilayah, perbelanjaan awam juga merupakan instrumen untuk mengenal pasti kewujudan eksternaliti negatif akibat kepadatan 
wilayah (bandar) atau eksternaliti positif akibat pemusatan bandar (De Mello, 2002). Namun, penentuan sama ada wujud eksternaliti negatif atau positif ini hanya boleh dilakukan menerusi perbandingan antara jumlah populasi semasa (L) dengan saiz populasi kritikal ( $\left.L^{\prime}\right)$. Contohnya, jika $\mathrm{L}<\mathrm{L}^{\prime}$, maka ini menunjukkan pemusatan wilayah menjana eksternaliti positif. Hal ini juga bererti, kerajaan negeri berupaya dan cenderung menawarkan pelbagai aktiviti ekonomi, sosial dan kebudayaan apabila saiz populasinya besar. Sebaliknya, jika L $>L^{\prime}$, ini mencerminkan kepadatan wilayah atau saiz populasi yang terlalu ramai akan hanya mewujudkan eksternaliti negatif seperti pencemaran, keganasan serta kesesakan lalu lintas. Oleh itu, memandangkan saiz populasi (POP) juga memberi impak kepada belanja, lantas persamaan (3) perlu diubah menjadi:

$$
G_{t}=a+\delta Y_{t}+\beta H C_{t}+\alpha I F_{t}+\gamma P O P_{t}+\mu_{t}
$$

Seperkara yang perlu ditegaskan di sini, disebabkan kebanyakan barangan awam bersifat tidak bersaingan dan tiada pengecualian terutama sekali bagi barang awam tulen, lantas jumlah belanja awam lebih bermakna kepada individu berbanding dengan jumlah per kapita (Barro, 1990). Justeru, semua pemboleh ubah dalam persamaan (4) bukan dalam bentuk per kapita. Tetapi kesan saiz negeri yang berbeza telah dikawal menerusi kehadiran pemboleh ubah populasi.

\section{Ujian Punca Unit (Unit root test)}

Sebelum ujian kointegrasi dan analisis sebab-menyebab antara perbelanjaan awam dengan output dilakukan, kepegunan setiap pemboleh ubah perlu ditentukan untuk mengelakkan masalah regresi palsu. Kepegunan setiap pemboleh ubah ditentukan menggunakan ujian Augmented Dickey-Fuller (ADF) yang diperkenalkan oleh Said dan Dickey (1984) seperti berikut:

$$
\Delta X_{t}=\eta_{0}+\eta_{1} X_{t-1}+\sum_{i=1}^{k} \eta_{i} \Delta X_{t-i}+\varepsilon_{t}
$$

yang mana $\Delta$ ialah operator pembezaan pertama, $\varepsilon_{\mathrm{t}}$ ialah sebutan ralat ganguan putih (white noise), dan $X_{t}$ ialah siri masa pemboleh ubah. Hipotesis yang perlu diuji ialah hipotesis nol: $\eta_{1}=0$, yang bererti wujud unit root (siri masa tidak pegun), manakala hipotesis alternatif: $\eta_{1}<0$, yang menunjukkan siri masa adalah pegun. Sekiranya hipotesis nol ditolak, maka ini menunjukkan siri 
masa $X_{t}$ adalah pegun dengan nilai min sifar. Bagi mengesahkan lagi keputusan ujian ADF tersebut, maka kajian ini turut melakukan ujian kepegunan Phillip Perron (PP).

\section{Ujian Kointegrasi Johansen}

Ujian kointegrasi Johansen yang diperkenalkan oleh Johansen dan Juselius (1990) boleh dilakukan jika semua pemboleh ubah siri masa mempunyai darjah integrasi yang sama, iaitu pegun pada peringkat pembezaan pertama atau I(1). Kaedah ini berdasarkan penganggaran kebolehjadian maksimum serta menguji vektor kointegrasi yang wujud dalam kalangan siri masa. Ujian kointegrasi ini juga menggunakan dua nilai statistik ujian iaitu ujian trace dan ujian max. Nilai statistik ujian ini kemudiannya akan dibandingkan dengan nilai kritikal yang diperoleh daripada Osterwald-Lenum (1992). Sekiranya nilai statistik ujian lebih besar daripada nilai kritikal ini pada aras keertian tertentu, maka wujud kointegrasi dalam kalangan pemboleh ubah yang terdapat dalam sistem.

\section{Model Vektor Pembetulan Ralat (VECM)}

Walaupun begitu, ujian kointegrasi Johansen tidak dapat mengenal pasti kewujudan hubungan sebab-menyebab dalam kalangan pemboleh ubah sirimasa tersebut. Jika pemboleh ubah-pemboleh ubah tersebut berkointegrasi pada darjah integrasi yang sama iaitu pada I(1), maka sebutan pembetulan ralat tertangguh perlu dimasukkan ke dalam model sebelum ujian sebab-menyebab Granger (1969) boleh dilakukan. Oleh yang demikian, persamaan (4) perlu dianggar dalam versi model VECM seperti berikut (dengan mengandaikan semua pemboleh ubah akan menjadi pemboleh ubah bersandar):

$$
\begin{aligned}
& \Delta G_{t}=\alpha_{10}+\lambda_{G} \hat{\varepsilon}_{t-1}+\sum_{i=1}^{n} \delta_{i t} \Delta G_{t i-i}+\sum_{i=1}^{n} \varphi_{i t} \Delta Y_{t i}+\sum_{i=1}^{n} \gamma_{i t} \Delta H C_{t i}+\sum_{i=1}^{n} \beta_{i t} \Delta F_{t i-}+\sum_{i=1}^{n} \chi_{i t} \Delta P O P_{t i}+\mu_{t i t} \\
& \Delta Y_{t}=\alpha_{20}+\lambda_{i} \hat{\varepsilon}_{t-1}+\sum_{i=1}^{n} \delta_{2 i} \Delta G_{t-i}+\sum_{i=1}^{n} \varphi_{i i} \Delta Y_{t-i}+\sum_{i=1}^{n} \gamma_{2 i} \Delta H C_{t-i}+\sum_{i=1}^{n} \beta_{2 i} \Delta I F_{t-i}+\sum_{i=1}^{n} \chi_{2 i} \Delta P O P_{t-i}+\mu_{2 t} \\
& \Delta H C_{t}=\alpha_{30}+\lambda_{H C} \hat{\epsilon}_{t-1}+\sum_{i=1}^{n} \delta_{3 i} \Delta G_{t-i}+\sum_{i=1}^{n} \varphi_{3 i} \Delta Y_{t-i}+\sum_{i=1}^{n} \gamma_{3} \Delta H C_{t-i}+\sum_{i=1}^{n} \beta_{3 i} \Delta I F_{t-i}+\sum_{i=1}^{n} \chi_{3 i} \Delta P O P_{t-i}+\mu_{3 t} \\
& \Delta I F_{t}=\alpha_{t 0}+\lambda_{t r} \hat{\theta}_{t-1}+\sum_{i=1}^{n} \delta_{t i} \Delta G_{t-i}+\sum_{i=1}^{n} \varphi_{t i t} \Delta Y_{t-i}+\sum_{i=1}^{n} \gamma_{t i} \Delta H C_{t i-}+\sum_{i=1}^{n} \beta_{t i} \Delta I F_{t-i}+\sum_{i=1}^{n} \chi_{t i} \Delta P O P_{t i-}+\mu_{t+t} \\
& \Delta P O P_{i}=\alpha_{s 0}+\lambda_{P O P} \hat{\theta}_{t-1}+\sum_{i=1}^{n} \delta_{s i} \Delta G_{t i-}+\sum_{i=1}^{n} \varphi_{s i} \Delta Y_{t i-i}+\sum_{i=1}^{n} \gamma_{s i} \Delta H C_{t i-}+\sum_{i=1}^{n} \beta_{s i} \Delta l F_{t i}+\sum_{i=1}^{n} \chi_{i t} \Delta P O P_{t i}+\mu_{s t}
\end{aligned}
$$


yang mana, $\Delta$ ialah operator pembezaan pertama, $\dot{\varepsilon}_{\mathrm{t}-1}$ ialah sebutan pembetulan ralat tertangguh iaitu ralat daripada persamaan vektor kointegrasi yang dihasilkan oleh ujian kointegrasi Johansen dan $\mu$ pula merujuk kepada sebutan ralat. Sebaliknya, jika ujian kointegrasi Johansen sebelum ini mendapati tidak wujud kointegrasi antara pemboleh ubah, maka sebutan pembetulan ralat tertangguh perlulah disingkirkan daripada persamaan VECM di atas.

Analisis model VECM juga dapat mengasingkan kesan jangka pendek dan jangka panjang pemboleh ubah penerang terhadap pemboleh ubah bersandar. Kesan jangka panjang ditentukan menerusi sebutan pembetulan ralat tertangguh yang mengukur kelajuan pelarasan (speed of adjustment) ke arah keseimbangan jangka panjang, iaitu masa yang diambil oleh pemboleh ubah penerang untuk menumpu (converge) ke arah keseimbangan jangka panjang. Ia juga menerangkan arah sebabmenyebab jangka panjang dalam kalangan pemboleh ubah penerang terhadap pemboleh ubah bersandar. Hubungan sebab-menyebab Granger jangka pendek pula dapat dikenal pasti melalui ujian wald (statistik F) terhadap sekumpulan koefisien yang berkenaan seperti berikut:

$$
\begin{aligned}
& \mathrm{H}_{0}: \delta_{2 n}=0, \delta_{3 n}=0, \delta_{4 n}=0, \delta_{5 n}=0 \text { melawan } \mathrm{H}_{1}: \delta_{2 n} \neq 0, \delta_{3 n} \neq 0, \delta_{4 n} \neq 0, \delta_{5 n} \neq 0 \\
& \mathrm{H}_{0}: \phi_{1 n}=0, \phi_{3 n}=0, \phi_{4 n}=0, \phi_{5 n}=0 \text { melawan } \mathrm{H}_{1}: \phi_{1 n} \neq 0, \phi_{3 n} \neq 0, \phi_{4 n} \neq 0, \phi_{5 n} \neq 0 \\
& \mathrm{H}_{0}: \gamma_{1 n}=0, \gamma_{2 n}=0, \gamma_{4 n}=0, \gamma_{5 n}=0 \text { melawan } \mathrm{H}_{1}: \gamma_{1 n} \neq 0, \gamma_{2 n} \neq 0, \gamma_{4 n} \neq 0, \gamma_{5 n} \neq 0 \\
& \mathrm{H}_{0}: \beta_{1 n}=0, \beta_{2 n}=0, \beta_{3 n}=0, \beta_{5 n}=0 \text { melawan } \mathrm{H}_{1}: \beta_{1 n} \neq 0, \beta_{2 n} \neq 0, \beta_{3 n} \neq 0, \beta_{5 n} \neq 0 \\
& \mathrm{H}_{0}: \chi_{1 n}=0, \chi_{2 n}=0, \chi_{3 n}=0, \chi_{4 n}=0 \text { melawan } \mathrm{H}_{1}: \chi_{1 n} \neq 0, \chi_{2 n} \neq 0, \chi_{3 n} \neq 0, \chi_{4 n} \neq 0
\end{aligned}
$$

\section{Data dan Definisi Pemboleh Ubah}

Kajian ini menggunakan lima data siri masa bagi setiap negeri di Semenanjung Malaysia, iaitu belanja awam (G), Keluaran Dalam Negeri Kasar (Y), jumlah hasil cukai (HC), imbangan fiskal (IF) dan jumlah populasi (POP). Untuk tujuan analisis, kesemua pemboleh ubah telah diubah suai dalam log semula jadi. Data fiskal (G, HC, IF) diperoleh daripada laporan kewangan tahunan negeri pelbagai tahun, manakala data output (Y) dan populasi (POP) didapati daripada laporan ekonomi negeri dan Rancangan Malaysia pelbagai tahun. Kajian ini menggunakan sampel data tahunan dari tahun 1970 hingga 2008 yang merangkumi tempoh selama 39 tahun. 


\section{Keputusan Empirikal}

Bahagian ini membincangkan keputusan ujian punca unit dengan menggunakan kaedah ADF dan PP, ujian kointegrasi Johansen serta ujian model VECM. Berdasarkan Jadual 1, didapati semua pemboleh ubah siri masa tidak mencapai kepegunan pada peringkat paras, I(0), tetapi mencapai kepegunan pada peringkat pembezaan pertama, I(1), iaitu pada aras keertian lima peratus. Keputusan ini membolehkan ujian kointegrasi Johansen dilakukan seterusnya.

Jadual 1

\section{Ujian Kepegunan ADF}

\begin{tabular}{|c|c|c|c|c|c|}
\hline \multirow[t]{2}{*}{ Negeri } & \multirow{2}{*}{$\begin{array}{c}\text { Pemboleh } \\
\text { ubah }\end{array}$} & \multicolumn{2}{|c|}{ Nilai statistik ADF } & \multicolumn{2}{|c|}{ Nilai statistik PP } \\
\hline & & Paras & $\begin{array}{c}\text { Pembezaan } \\
\text { pertama }\end{array}$ & Paras & $\begin{array}{r}\text { Pembezaan } \\
\text { pertama }\end{array}$ \\
\hline Selangor & $\begin{array}{c}\mathrm{G} \\
\mathrm{Y} \\
\mathrm{HC} \\
\mathrm{IF} \\
\mathrm{POP}\end{array}$ & $\begin{array}{r}-2.6875(0) \\
-1.9587(0) \\
-0.1790(2) \\
-1.0820(1) \\
0.4393(0)\end{array}$ & $\begin{array}{l}-5.7586^{*}(0) \\
-7.0422^{*}(0) \\
-6.6101^{*}(1) \\
-9.0877^{*}(0) \\
-5.3002^{*}(0)\end{array}$ & $\begin{array}{l}-2.8734(4) \\
-1.9587(0) \\
-0.4618(1) \\
-1.4752(2) \\
-1.5157(2)\end{array}$ & $\begin{array}{r}-6.0164^{*}(4) \\
-7.0488^{*}(1) \\
-10.4612^{*}(3) \\
-9.2141^{*}(2) \\
-5.4033^{*}(1)\end{array}$ \\
\hline Perlis & $\begin{array}{l}\text { G } \\
\text { Y } \\
\text { HC } \\
\text { IF } \\
\text { POP }\end{array}$ & $\begin{array}{l}-1.8449(2) \\
-0.3274(0) \\
-0.6846(1) \\
-2.5345(2) \\
-1.2583(0)\end{array}$ & $\begin{array}{r}-9.9723^{*}(0) \\
-5.7044^{*}(0) \\
-11.8391^{*}(0) \\
-4.2345^{*}(3) \\
-5.2491^{*}(0)\end{array}$ & $\begin{array}{l}-2.0538(5) \\
-0.3128(3) \\
-1.7589(1) \\
-1.8696(4) \\
-2.2252(5)\end{array}$ & $\begin{array}{r}-11.6883^{*}(5) \\
-5.6948^{*}(4) \\
-12.9006^{*}(5) \\
-12.3426^{*}(7) \\
-5.7142^{*}(2)\end{array}$ \\
\hline Negeri Sembilan & $\begin{array}{c}\text { G } \\
\text { Y } \\
\text { HC } \\
\text { IF } \\
\text { POP }\end{array}$ & $\begin{array}{l}-2.3514(0) \\
-0.2192(0) \\
-1.2042(0) \\
-2.3566(0) \\
-0.9999(0)\end{array}$ & $\begin{array}{l}-5.9813^{*}(0) \\
-6.1525^{*}(0) \\
-5.8098^{*}(1) \\
-6.5182^{*}(0) \\
-6.0185^{*}(9)\end{array}$ & $\begin{array}{l}-2.3623(2) \\
-0.1464(4) \\
-1.2183(13) \\
-2.5024(3) \\
-1.0535(3)\end{array}$ & $\begin{array}{r}-5.9829^{*}(1) \\
-6.1861^{*}(4) \\
-9.6034^{*}(11) \\
-6.5182^{*}(0) \\
-6.1969^{*}(3)\end{array}$ \\
\hline Kedah & $\begin{array}{l}\text { G } \\
\text { Y } \\
\text { HC } \\
\text { IF } \\
\text { POP }\end{array}$ & $\begin{array}{l}-1.4925(0) \\
-0.6162(0) \\
-0.2357(0) \\
-0.5361(2) \\
-0.2497(0)\end{array}$ & $\begin{array}{l}-5.6140^{*}(0) \\
-6.5250^{*}(0) \\
-7.3039^{*}(0) \\
-7.6042^{*}(0) \\
-6.2097^{*}(0)\end{array}$ & $\begin{array}{l}-1.5320(7) \\
-0.5844(5) \\
-0.1193(5) \\
-1.0028(2) \\
-0.2269(4)\end{array}$ & $\begin{array}{l}-6.1166^{*}(8) \\
-6.7793^{*}(5) \\
-7.2983^{*}(2) \\
-9.5736^{*}(9) \\
-6.2711^{*}(4)\end{array}$ \\
\hline Kelantan & $\begin{array}{l}\text { G } \\
\text { Y } \\
\text { HC } \\
\text { IF } \\
\text { POP }\end{array}$ & $\begin{array}{l}-1.9254(0) \\
-1.1562(0) \\
-1.7483(4) \\
-2.4043(0) \\
-1.8545(2)\end{array}$ & $\begin{array}{l}-6.4725^{*}(0) \\
-6.3224^{*}(0) \\
-6.6019^{*}(1) \\
-7.0834^{*}(0) \\
-5.7467^{*}(9)\end{array}$ & $\begin{array}{l}-1.9254(0) \\
-1.1963(3) \\
-1.5287(5) \\
-2.3630(1) \\
-1.2562(4)\end{array}$ & $\begin{array}{r}-6.4739^{*}(2) \\
-6.3299^{*}(2) \\
-17.2624^{*}(6) \\
-7.2644^{*}(6) \\
-9.3388^{*}(3)\end{array}$ \\
\hline Terengganu & $\begin{array}{l}\text { G } \\
\text { Y } \\
\text { HC } \\
\text { IF } \\
\text { POP }\end{array}$ & $\begin{array}{l}-1.7962(1) \\
-1.9214(0) \\
-1.8218(0) \\
-2.5815(0) \\
-1.7492(1)\end{array}$ & $\begin{array}{l}-3.8001^{*}(0) \\
-5.8200^{*}(0) \\
-5.3845^{*}(0) \\
-7.6403^{*}(0) \\
-3.7993^{*}(0)\end{array}$ & $\begin{array}{l}-1.6003(2) \\
-2.0260(3) \\
-1.8539(2) \\
-2.6062(3) \\
-1.8585(4)\end{array}$ & $\begin{array}{l}-3.7962^{*}(1) \\
-5.8200^{*}(1) \\
-5.3989^{*}(2) \\
-7.6784^{*}(1) \\
-3.8586^{*}(3)\end{array}$ \\
\hline
\end{tabular}

(sambungan) 
IJMS 19 (2), 125-150 (2012)

\begin{tabular}{lcccrr}
\hline Negeri & $\begin{array}{c}\text { Pemboleh } \\
\text { ubah }\end{array}$ & \multicolumn{2}{c}{ Nilai statistik ADF } & \multicolumn{2}{c}{ Nilai statistik PP } \\
\cline { 2 - 6 } & & Paras & $\begin{array}{c}\text { Pembezaan } \\
\text { pertama }\end{array}$ & Paras & $\begin{array}{r}\text { Pembezaan } \\
\text { pertama }\end{array}$ \\
\hline Pahang & G & $-2.5219(8)$ & $-6.6744^{*}(1)$ & $-2.3504(0)$ & $-9.0698^{*}(0)$ \\
& Y & $-0.6666(0)$ & $-6.2148^{*}(0)$ & $-0.6504(3)$ & $-6.2315^{*}(3)$ \\
& HC & $-0.9868(7)$ & $-3.6771^{*}(6)$ & $-1.4758(7)$ & $-10.0149^{*}(12)$ \\
& IF & $-0.8247(3)$ & $-6.7282^{*}(2)$ & $-2.7729(3)$ & $-16.9862^{*}(3)$ \\
Johor & POP & $-1.8875(0)$ & $-5.6104^{*}(0)$ & $-1.9228(2)$ & $-5.6099^{*}(1)$ \\
& G & $-2.4538(7)$ & $-5.0249^{*}(2)$ & $-3.1279(0)$ & $-6.6857^{*}(1)$ \\
& Y & $-0.7396(0)$ & $-6.3824^{*}(0)$ & $-0.7912(5)$ & $-6.5565^{*}(5)$ \\
& HC & $-0.6422(0)$ & $-6.5601^{*}(0)$ & $-0.5972(6)$ & $-7.3126^{*}(10)$ \\
Melaka & IF & $-1.7281(0)$ & $-8.0277^{*}(0)$ & $-1.7281(0)$ & $-10.6043^{*}(6)$ \\
& POP & $-1.9021(0)$ & $-4.9604^{*}(0)$ & $-1.7171(2)$ & $-4.9702^{*}(2)$ \\
& G & $-1.6911(2)$ & $-6.5500^{*}(1)$ & $-1.5907(3)$ & $-10.4475^{*}(6)$ \\
& Y & $-0.0524(0)$ & $-6.2716^{*}(0)$ & $-2.9514(1)$ & $-6.4429^{*}(6)$ \\
& HC & $-2.9371(0)$ & $-6.8821^{*}(0)$ & $-2.9649(1)$ & $-6.8821^{*}(0)$ \\
Perak & IF & $-0.8163(2)$ & $-6.9074^{*}(1)$ & $-1.5401(2)$ & $-12.8948^{*}(11)$ \\
& POP & $-0.4829(0)$ & $-6.2191^{*}(0)$ & $-0.4609(3)$ & $-6.2715^{*}(4)$ \\
& G & $-2.0316(9)$ & $-3.0711^{*}(9)$ & $-1.9060(10)$ & $-6.4169^{*}(6)$ \\
& Y & $-0.8619(0)$ & $-6.2966^{*}(0)$ & $-0.8707(3)$ & $-6.3153^{*}(3)$ \\
& HC & $-0.2539(0)$ & $-5.3155^{*}(9)$ & $-3.1912(3)$ & $-8.6429^{*}(11)$ \\
& IF & $-0.1001(6)$ & $-2.5983^{*}(8)$ & $-1.0933(7)$ & $-14.4152^{*}(16)$ \\
& POP & $-1.8806(0)$ & $-5.8076^{*}(0)$ & $-1.8443(0)$ & $-5.8181^{*}(0)$ \\
Pulau Pinang & G & $-1.5124(4)$ & $-3.1311^{*}(9)$ & $-0.8329(4)$ & $-10.0799^{*}(2)$ \\
& Y & $-0.2315(0)$ & $-6.0946^{*}(0)$ & $-0.1877(4)$ & $-6.1248^{*}(4)$ \\
& HC & $-0.7429(0)$ & $-7.5585^{*}(0)$ & $-2.7403(1)$ & $-8.5224^{*}(11)$ \\
& IF & $-1.8267(1)$ & $-6.4022^{*}(1)$ & $-2.5754(1)$ & $-8.8716^{*}(1)$ \\
& POP & $-1.4417(0)$ & $-4.9064^{*}(0)$ & $-1.2584(3)$ & $-4.9014^{*}(2)$ \\
\hline & & & & &
\end{tabular}

Nota. Model ini dijana dengan pintasan. Nilai dalam kurungan menunjukkan lat optimum yang ditentukan menerusi kaedah Akaike Info Criterion (AIC). *signifikan pada aras keertian $5 \%$.

Jadual 2 menunjukkan keputusan ujian kointegrasi Johansen berdasarkan statistik ujian Trace dan Max-Eigen. Keputusan ujian menunjukkan Selangor satu-satunya negeri di Semenanjung Malaysia yang tidak menunjukkan hubungan jangka panjang antara pemboleh ubah belanja awam dengan output negeri, hasil cukai, imbangan fiskal serta populasi. Hal ini mungkin disebabkan Selangor sebuah negeri maju dan terletak paling hampir dengan ibu negara yakni Kuala Lumpur yang memudahkan ia menarik sejumlah besar pelaburan swasta domestik mahupun asing. Sebaliknya, hipotesis nol $(\mathrm{r}=0)$ yang menggambarkan tidak wujud sekurang-kurangnya satu vektor yang berkointegrasi berjaya ditolak di negeri-negeri lain. Hal ini bererti, wujud sekurang-kurangnya satu vektor persamaan yang berkointegrasi di negeri-negeri tersebut (selain Selangor). Secara spesifiknya, hipotesis ini signifikan pada aras keertian lima peratus di Perlis, Kelantan, Terengganu, Johor dan Perak mengikut kedua- 
dua statistik, lima peratus berdasarkan ujian statistik Trace sahaja di Negeri Sembilan dan Pulau Pinang, sepuluh peratus mengikut kedua-dua statistik di Kedah, sepuluh peratus berasaskan statistik Trace sahaja di Melaka, serta lima peratus mengikut statistik Trace dan sepuluh peratus berdasarkan statistik Max-Eigen di Pahang. Dalam masa yang sama, dapatan turut menjelaskan bahawa terdapat juga kes kerajaan negeri yang wujud sekurang-kurangnya satu vektor kointegrasi antara pemboleh ubah yang dikaji pada aras keertian berbeza iaitu lima peratus berasaskan statistik Trace di Perlis, lima peratus berdasarkan kedua-dua statistik di Kelantan, sepuluh peratus mengikut statistik Trace di Negeri Sembilan dan Pulau Pinang serta sepuluh peratus berdasarkan kedua-dua statistik di Pahang. Di Perak pula wujud sekurang-kurangnya tiga vektor kointegrasi yang signifikan pada aras keertian sepuluh peratus mengikut statistik Trace.

Jadual 2

Ujian Kointegrasi Johansen

\begin{tabular}{|c|c|c|c|c|c|c|}
\hline Negeri & $\begin{array}{c}\text { Hipotesis } \\
\text { nol }\end{array}$ & $\begin{array}{l}\text { Nilai } \\
\text { Eigen }\end{array}$ & $\begin{array}{c}\text { Statistik } \\
\text { Trace }\end{array}$ & $\begin{array}{c}\text { Nilai } \\
\text { kritikal 5\% }\end{array}$ & $\begin{array}{c}\text { Statistik } \\
\text { Max-Eigen }\end{array}$ & $\begin{array}{c}\text { Nilai } \\
\text { kritikal 5\% }\end{array}$ \\
\hline \multirow[t]{4}{*}{ Selangor } & $\mathrm{r}=0$ & 0.4764 & 56.1371 & 76.9728 & 23.9384 & 34.8059 \\
\hline & $\mathrm{r} \leq 1$ & 0.2932 & 32.1987 & 54.079 & 12.8391 & 28.5881 \\
\hline & $r \leq 2$ & 0.2033 & 19.3596 & 35.1928 & 8.4071 & 22.2996 \\
\hline & $r \leq 3$ & 0.1723 & 10.9526 & 20.2618 & 6.9954 & 15.8921 \\
\hline \multirow[t]{4}{*}{ Perlis } & $\mathrm{r}=0$ & 0.6469 & $93.3729^{*}$ & 76.9728 & $38.5138^{*}$ & 34.8059 \\
\hline & $\mathrm{r} \leq 1$ & 0.4239 & $54.8591^{*}$ & 54.079 & 20.4094 & 28.5881 \\
\hline & $r \leq 2$ & 0.3752 & 34.4497 & 35.1928 & 17.4005 & 22.2996 \\
\hline & $r \leq 3$ & 0.2501 & 17.0492 & 20.2618 & 10.648 & 15.8921 \\
\hline Negeri & $\mathrm{r}=0$ & 0.5408 & $79.5362^{*}$ & 76.9728 & 28.7941 & 34.8059 \\
\hline \multirow[t]{3}{*}{ Sembilan } & $\mathrm{r} \leq 1$ & 0.4637 & $50.7420^{* *}$ & 54.079 & 23.054 & 28.5881 \\
\hline & $r \leq 2$ & 0.3287 & 27.688 & 35.1928 & 14.7465 & 22.2996 \\
\hline & $r \leq 3$ & 0.2431 & 12.9415 & 20.2618 & 10.3037 & 15.8921 \\
\hline \multirow[t]{4}{*}{ Kedah } & $\mathrm{r}=0$ & 0.5657 & $75.1071^{* *}$ & 76.9728 & $33.5042^{* *}$ & 34.8059 \\
\hline & $\mathrm{r} \leq 1$ & 0.4086 & 41.6029 & 54.079 & 19.4362 & 28.5881 \\
\hline & $r \leq 2$ & 0.3181 & 22.1667 & 35.1928 & 14.1676 & 22.2996 \\
\hline & $r \leq 3$ & 0.1283 & 7.9992 & 20.2618 & 5.0809 & 15.8921 \\
\hline \multirow[t]{4}{*}{ Kelantan } & $\mathrm{r}=0$ & 0.6118 & $95.5009^{*}$ & 76.9728 & $35.0079^{*}$ & 34.8059 \\
\hline & $\mathrm{r} \leq 1$ & 0.5469 & $60.4929^{*}$ & 54.0790 & $29.2911^{*}$ & 28.5881 \\
\hline & $r \leq 2$ & 0.3484 & 31.2019 & 35.1928 & 15.8477 & 22.2996 \\
\hline & $r \leq 3$ & 0.2357 & 15.3542 & 20.2618 & 9.9442 & 15.8921 \\
\hline
\end{tabular}

(sambungan) 
IJMS 19 (2), 125-150 (2012)

\begin{tabular}{|c|c|c|c|c|c|c|}
\hline Negeri & $\begin{array}{l}\text { Hipotesis } \\
\text { nol }\end{array}$ & $\begin{array}{l}\text { Nilai } \\
\text { Eigen }\end{array}$ & $\begin{array}{l}\text { Statistik } \\
\text { Trace }\end{array}$ & $\begin{array}{c}\text { Nilai } \\
\text { kritikal 5\% }\end{array}$ & $\begin{array}{c}\text { Statistik } \\
\text { Max-Eigen }\end{array}$ & $\begin{array}{c}\text { Nilai } \\
\text { kritikal 5\% }\end{array}$ \\
\hline \multirow[t]{4}{*}{ Terengganu } & $\mathrm{r}=0$ & 0.6468 & $88.2518^{*}$ & 76.97277 & $38.50818^{*}$ & 34.80587 \\
\hline & $r \leq 1$ & 0.4699 & 49.7437 & 54.07904 & 23.48759 & 28.58808 \\
\hline & $r \leq 2$ & 0.2935 & 26.2561 & 35.19275 & 12.85296 & 22.29962 \\
\hline & $r \leq 3$ & 0.1929 & 13.4031 & 20.26184 & 7.927773 & 15.89210 \\
\hline \multirow[t]{4}{*}{ Pahang } & $\mathrm{r}=0$ & 0.5904 & $84.1739 *$ & 76.9728 & $33.0237^{* *}$ & 34.8059 \\
\hline & $\mathrm{r} \leq 1$ & 0.5356 & $51.1502^{* *}$ & 54.0790 & $28.3842^{* *}$ & 28.5881 \\
\hline & $r \leq 2$ & 0.3247 & 22.7661 & 35.1928 & 14.5288 & 22.2996 \\
\hline & $r \leq 3$ & 0.1399 & 8.2373 & 20.2618 & 5.5743 & 15.8921 \\
\hline \multirow[t]{4}{*}{ Johor } & $\mathrm{r}=0$ & 0.6946 & $85.6722^{*}$ & 76.9728 & $43.8909^{*}$ & 34.8059 \\
\hline & $r \leq 1$ & 0.3796 & 41.7812 & 54.0790 & 17.6637 & 28.5881 \\
\hline & $r \leq 2$ & 0.3085 & 24.1175 & 35.1928 & 13.6495 & 22.2996 \\
\hline & $r \leq 3$ & 0.1725 & 10.4680 & 20.2618 & 7.0040 & 15.8921 \\
\hline \multirow[t]{4}{*}{ Melaka } & $\mathrm{r}=0$ & 0.5449 & $73.2147^{* *}$ & 76.9728 & 29.1308 & 34.8059 \\
\hline & $\mathrm{r} \leq 1$ & 0.4348 & 44.0838 & 54.0790 & 21.1135 & 28.5881 \\
\hline & $r \leq 2$ & 0.2401 & 22.9704 & 35.1928 & 10.1608 & 22.2996 \\
\hline & $r \leq 3$ & 0.1888 & 12.8096 & 20.2618 & 7.7411 & 15.8921 \\
\hline \multirow[t]{4}{*}{$\overline{\text { Perak }}$} & $\mathrm{r}=0$ & 0.6624 & $97.0346^{*}$ & 76.9728 & $40.1753^{*}$ & 34.8059 \\
\hline & $r \leq 1$ & 0.4294 & $56.8593^{*}$ & 54.0790 & 20.7616 & 28.5881 \\
\hline & $r \leq 2$ & 0.3847 & $36.0977^{*}$ & 35.1928 & 17.9682 & 22.2996 \\
\hline & $r \leq 3$ & 0.2960 & $18.1295^{* *}$ & 20.2618 & 12.9877 & 15.8921 \\
\hline \multirow[t]{4}{*}{ Pulau Pinang } & $\mathrm{r}=0$ & 0.5787 & $82.5978^{*}$ & 76.9728 & 31.9843 & 34.8059 \\
\hline & $r \leq 1$ & 0.4833 & $50.6135^{* *}$ & 54.0790 & 24.4294 & 28.5881 \\
\hline & $r \leq 2$ & 0.2884 & 26.1842 & 35.1928 & 12.5875 & 22.2996 \\
\hline & $r \leq 3$ & 0.2253 & 13.5967 & 20.2618 & 9.4458 & 15.8921 \\
\hline
\end{tabular}

Nota. Model ini dijana dengan pintasan. Lat optimum adalah satu yang ditentukan menerusi kaedah Akaike Info Criterion (AIC). *signifikan pada aras keertian 5\%. ${ }^{* *}$ signifikan pada aras keertian $10 \%$.

Selanjutnya, Jadual 3 pula memaparkan keputusan ujian sebabmenyebab Granger versi VECM. Berdasarkan ujian kointegrasi Johansen sebelum ini, sebutan pembetulan ralat tertangguh akan dimasukkan ke dalam model kecuali bagi kes Selangor kerana keduadua statistik ujian Trace dan Max-Eigen tidak signifikan. Jika diamati, keputusan di Jadual 3 sebenarnya menunjukkan kewujudan pelbagai bentuk hubungan antara pemboleh ubah. Bagi kerajaan negeri Perlis, imbangan fiskal dan populasi mempunyai hubungan dua hala dan turut dipengaruh oleh pemboleh ubah lain dalam jangka panjang. Manakala, dalam jangka pendek, populasi dan imbangan fiskal 
berhubungan dua hala, populasi turut mempengaruhi belanja awam, serta belanja awam dan hasil cukai menjadi penyebab Granger kepada imbangan fiskal. Jelas sekali di Perlis, imbangan fiskal dan populasi saling mempengaruhi dalam jangka panjang mahupun jangka pendek. Di Negeri Sembilan pula, hasil cukai dan populasi saling mempengaruhi dan turut dipengaruh oleh pemboleh ubah lain dalam jangka panjang. Dapatan dalam jangka pendek pula membuktikan output negeri dan hasil cukai mempunyai hubungan dua hala di samping hasil cukai turut dipengaruh oleh populasi. Manakala output turut menjadi penyebab Granger jangka pendek kepada belanja awam dan populasi serta hasil cukai mempengaruhi imbangan fiskal.

\section{Jadual 3}

\section{Ujian Penyebab Granger Versi VECM}

\begin{tabular}{|c|c|c|c|c|c|c|}
\hline \multirow[t]{2}{*}{ Negeri } & \multirow{2}{*}{$\begin{array}{l}\text { Pemboleh } \\
\text { ubah bebas }\end{array}$} & \multicolumn{5}{|c|}{ Pemboleh ubah bersandar } \\
\hline & & $\Delta \mathrm{G}$ & $\Delta \mathrm{Y}$ & $\Delta \mathrm{HC}$ & $\Delta \mathrm{IF}$ & $\triangle \mathrm{POP}$ \\
\hline \multirow[t]{6}{*}{ Perlis } & $\dot{\varepsilon}_{t-1}$ & $\begin{array}{c}0.3057 \\
{[1.3195]}\end{array}$ & $\begin{array}{c}-0.0172 \\
{[-0.3008]}\end{array}$ & $\begin{array}{c}0.2177 \\
{[0.7643]}\end{array}$ & $\begin{array}{c}-0.7721 \\
{[-3.7678]^{*}}\end{array}$ & $\begin{array}{c}-0.0041 \\
{[-3.6690]^{*}}\end{array}$ \\
\hline & $\Delta \mathrm{G}_{\mathrm{t}-1}$ & $\begin{array}{c}-0.6353 \\
{[-2.0468]^{* *}}\end{array}$ & $\begin{array}{c}0.0317 \\
{[0.4134]}\end{array}$ & $\begin{array}{c}-0.4675 \\
{[-1.2251]}\end{array}$ & $\begin{array}{l}0.4681 \\
{[1.7053]^{* * * *}}\end{array}$ & $\begin{array}{c}0.0006 \\
{[0.4363]}\end{array}$ \\
\hline & $\Delta \mathrm{Y}_{\mathrm{t}-1}$ & $\begin{array}{c}-0.6541 \\
{[-0.8972]}\end{array}$ & $\begin{array}{c}0.0975 \\
{[0.5418]}\end{array}$ & $\begin{array}{c}-0.0315 \\
{[-0.0351]}\end{array}$ & $\begin{array}{c}0.0215 \\
{[0.0334]}\end{array}$ & $\begin{array}{c}-0.0028 \\
{[-0.7965]}\end{array}$ \\
\hline & $\Delta \mathrm{HC}_{\mathrm{t}-1}$ & $\begin{array}{c}-0.0843 \\
{[-0.3446]}\end{array}$ & $\begin{array}{c}-0.0296 \\
{[-0.4902]}\end{array}$ & $\begin{array}{l}-0.6747 \\
{[-2.2427]^{* *}}\end{array}$ & $\begin{array}{c}-0.6069 \\
{[-2.8045]^{*}}\end{array}$ & $\begin{array}{c}-0.0009 \\
{[-0.7622]}\end{array}$ \\
\hline & $\Delta \mathrm{IF}_{\mathrm{t}-1}$ & $\begin{array}{c}-0.2751 \\
{[-0.8530]}\end{array}$ & $\begin{array}{c}-0.0366 \\
{[-0.4600]}\end{array}$ & $\begin{array}{c}-0.3267 \\
{[-0.8239]}\end{array}$ & $\begin{array}{c}0.4239 \\
{[1.4864]}\end{array}$ & $\begin{array}{l}0.0031 \\
{[2.0186]^{* * *}}\end{array}$ \\
\hline & $\Delta \mathrm{POP}_{\mathrm{t}-1}$ & $\begin{array}{l}27.9795 \\
{[2.4801]^{* *}}\end{array}$ & $\begin{array}{c}3.1129 \\
{[1.1181]}\end{array}$ & $\begin{array}{l}22.3819 \\
{[1.6136]}\end{array}$ & $\begin{array}{l}-37.0832 \\
{[-3.7167]^{*}}\end{array}$ & $\begin{array}{c}0.8104 \\
{[15.0586]^{*}}\end{array}$ \\
\hline \multirow[t]{6}{*}{$\begin{array}{l}\text { Negeri } \\
\text { Sembilan }\end{array}$} & $\dot{\varepsilon}_{\mathrm{t}-1}$ & $\begin{array}{c}-0.0024 \\
{[-0.1358]}\end{array}$ & $\begin{array}{c}-0.0093 \\
{[-0.4779]}\end{array}$ & $\begin{array}{c}0.0504 \\
{[2.4406]^{* *}}\end{array}$ & $\begin{array}{c}0.0279 \\
{[1.3032]}\end{array}$ & $\begin{array}{c}-0.0039 \\
{[-2.9156]^{*}}\end{array}$ \\
\hline & $\Delta \mathrm{G}_{\mathrm{t}-1}$ & $\begin{array}{c}0.0024 \\
{[0.0144]}\end{array}$ & $\begin{array}{c}0.2207 \\
{[1.1912]}\end{array}$ & $\begin{array}{c}0.1941 \\
{[0.9880]}\end{array}$ & $\begin{array}{c}-0.2144 \\
{[-1.0541]}\end{array}$ & $\begin{array}{c}-0.0007 \\
{[-0.0526]}\end{array}$ \\
\hline & $\Delta \mathrm{Y}_{\mathrm{t}-1}$ & $\begin{array}{c}0.5031 \\
{[3.0232]^{*}}\end{array}$ & $\begin{array}{c}0.0653 \\
{[0.3594]}\end{array}$ & $\begin{array}{c}0.6338 \\
{[3.2893]^{*}}\end{array}$ & $\begin{array}{c}0.2546 \\
{[1.2763]}\end{array}$ & $\begin{array}{l}0.0218 \\
{[1.7365]^{* * * *}}\end{array}$ \\
\hline & $\Delta \mathrm{HC}_{\mathrm{t}-1}$ & $\begin{array}{c}-0.2509 \\
{[-1.6129]}\end{array}$ & $\begin{array}{l}-0.3071 \\
{[-1.8083]^{* * *}}\end{array}$ & $\begin{array}{c}-0.1388 \\
{[-0.7707]}\end{array}$ & $\begin{array}{l}0.3232 \\
{[1.7330]^{* * *}}\end{array}$ & $\begin{array}{c}0.0066 \\
{[0.5599]}\end{array}$ \\
\hline & $\Delta \mathrm{IF}_{\mathrm{t}-1}$ & $\begin{array}{c}0.0592 \\
{[0.3437]}\end{array}$ & $\begin{array}{c}0.0603 \\
{[0.3206]}\end{array}$ & $\begin{array}{l}8.20 \mathrm{E}-05 \\
{[0.0004]}\end{array}$ & $\begin{array}{c}-0.2360 \\
{[-1.1439]}\end{array}$ & $\begin{array}{c}-0.0042 \\
{[-0.3253]}\end{array}$ \\
\hline & $\Delta \mathrm{POP}_{\mathrm{t}-1}$ & $\begin{array}{c}1.2586 \\
{[0.4395]}\end{array}$ & $\begin{array}{c}2.9273 \\
{[0.9364]}\end{array}$ & $\begin{array}{c}9.2939 \\
{[2.8031]^{*}}\end{array}$ & $\begin{array}{c}3.4036 \\
{[0.9916]}\end{array}$ & $\begin{array}{c}0.0844 \\
{[0.3913]}\end{array}$ \\
\hline
\end{tabular}

(sambungan) 
IJMS 19 (2), 125-150 (2012)

\begin{tabular}{|c|c|c|c|c|c|c|}
\hline \multirow[t]{2}{*}{ Negeri } & \multirow{2}{*}{$\begin{array}{l}\text { Pemboleh } \\
\text { ubah bebas }\end{array}$} & \multicolumn{5}{|c|}{ Pemboleh ubah bersandar } \\
\hline & & $\Delta \mathrm{G}$ & $\Delta \mathrm{Y}$ & $\Delta \mathrm{HC}$ & $\Delta \mathrm{IF}$ & $\triangle \mathrm{POP}$ \\
\hline \multirow[t]{6}{*}{ Kedah } & $\dot{\varepsilon}_{\mathrm{t}-1}$ & $\begin{array}{l}0.5630 \\
{[2.3281]^{* *}}\end{array}$ & $\begin{array}{c}0.2661 \\
{[1.6048]}\end{array}$ & $\begin{array}{c}0.1435 \\
{[0.6511]}\end{array}$ & $\begin{array}{c}-1.0809 \\
{[-4.5633]^{*}}\end{array}$ & $\begin{array}{c}-0.0120 \\
{[-0.7291]}\end{array}$ \\
\hline & $\Delta \mathrm{G}_{\mathrm{t}-1}$ & $\begin{array}{c}-0.3522 \\
{[-1.5074]}\end{array}$ & $\begin{array}{c}-0.1018 \\
{[-0.6356]}\end{array}$ & $\begin{array}{l}-0.4155 \\
{[-1.9517]^{* * *}}\end{array}$ & $\begin{array}{c}-0.1438 \\
{[-0.6281]}\end{array}$ & $\begin{array}{l}0.0322 \\
{[2.0165]^{* * * *}}\end{array}$ \\
\hline & $\Delta \mathrm{Y}_{\mathrm{t}-1}$ & $\begin{array}{l}0.6303 \\
{[2.3619]^{* *}}\end{array}$ & $\begin{array}{c}0.2676 \\
{[1.4627]}\end{array}$ & $\begin{array}{l}0.5097 \\
{[2.0964]^{* *}}\end{array}$ & $\begin{array}{c}-0.1283 \\
{[-0.4908]}\end{array}$ & $\begin{array}{l}0.0459 \\
{[2.5219]^{* *}}\end{array}$ \\
\hline & $\Delta \mathrm{HC}_{\mathrm{t}-1}$ & $\begin{array}{l}0.5349 \\
{[2.4236]^{* *}}\end{array}$ & $\begin{array}{c}0.1785 \\
{[1.1794]}\end{array}$ & $\begin{array}{c}0.0197 \\
{[0.0978]}\end{array}$ & $\begin{array}{l}-0.3746 \\
{[-1.7330]^{* * *}}\end{array}$ & $\begin{array}{c}-0.0160 \\
{[-1.0626]}\end{array}$ \\
\hline & $\Delta \mathrm{IF}_{\mathrm{t}-1}$ & $\begin{array}{l}-0.5465 \\
{[-1.7198]^{* * * *}}\end{array}$ & $\begin{array}{c}-0.1134 \\
{[-0.5203]}\end{array}$ & $\begin{array}{c}-0.3836 \\
{[-1.3249]}\end{array}$ & $\begin{array}{c}0.3351 \\
{[1.0768]}\end{array}$ & $\begin{array}{l}\text { 4.17E-06 } \\
{[0.0002]}\end{array}$ \\
\hline & $\Delta \mathrm{POP}_{\mathrm{t}-1}$ & $\begin{array}{c}0.3896 \\
{[0.2359]}\end{array}$ & $\begin{array}{l}2.6902 \\
{[2.3758]^{* *}}\end{array}$ & $\begin{array}{l}3.5465 \\
{[2.3572]^{* *}}\end{array}$ & $\begin{array}{c}0.8652 \\
{[0.5349]}\end{array}$ & $\begin{array}{c}0.6265 \\
{[5.5567]^{*}}\end{array}$ \\
\hline \multirow[t]{6}{*}{ Kelantan } & $\dot{\varepsilon}_{\mathrm{t}-1}$ & $\begin{array}{c}0.2719 \\
{[0.8114]}\end{array}$ & $\begin{array}{c}0.2394 \\
{[1.4622]}\end{array}$ & $\begin{array}{c}-0.0739 \\
{[-0.2122]}\end{array}$ & $\begin{array}{c}-1.5712 \\
{[-4.3793]^{*}}\end{array}$ & $\begin{array}{c}-0.0086 \\
{[-1.1336]}\end{array}$ \\
\hline & $\Delta \mathrm{G}_{\mathrm{t}-1}$ & $\begin{array}{l}-0.4601 \\
{[-1.8255]^{* * *}}\end{array}$ & $\begin{array}{c}0.0829 \\
{[0.6739]}\end{array}$ & $\begin{array}{c}0.1314 \\
{[0.5012]}\end{array}$ & $\begin{array}{l}0.5188 \\
{[1.9223]^{* * *}}\end{array}$ & $\begin{array}{c}0.0070 \\
{[1.2299]}\end{array}$ \\
\hline & $\Delta \mathrm{Y}_{\mathrm{t}-1}$ & $\begin{array}{c}-0.0621 \\
{[-0.1968]}\end{array}$ & $\begin{array}{c}-0.0239 \\
{[-0.1554]}\end{array}$ & $\begin{array}{c}-0.2161 \\
{[-0.6582]}\end{array}$ & $\begin{array}{c}0.3399 \\
{[1.0061]}\end{array}$ & $\begin{array}{c}0.0204 \\
{[2.8421]^{*}}\end{array}$ \\
\hline & $\Delta \mathrm{HC}_{\mathrm{t}-1}$ & $\begin{array}{c}0.0060 \\
{[0.0412]}\end{array}$ & $\begin{array}{c}0.0718 \\
{[1.0058]}\end{array}$ & $\begin{array}{c}-0.7654 \\
{[-5.0339]^{*}}\end{array}$ & $\begin{array}{c}0.0579 \\
{[0.3700]}\end{array}$ & $\begin{array}{c}-0.0113 \\
{[-3.4005]^{*}}\end{array}$ \\
\hline & $\Delta \mathrm{IF}_{\mathrm{t}-1}$ & $\begin{array}{l}-0.5219 \\
{[-2.1971]^{* *}}\end{array}$ & $\begin{array}{l}-0.2219 \\
{[-1.9122]^{* * * *}}\end{array}$ & $\begin{array}{c}0.1058 \\
{[0.4281]}\end{array}$ & $\begin{array}{l}0.6098 \\
{[2.3976]^{* *}}\end{array}$ & $\begin{array}{c}0.0089 \\
{[1.6663]}\end{array}$ \\
\hline & $\Delta \mathrm{POP}_{\mathrm{t}-1}$ & $\begin{array}{l}5.7764 \\
{[2.2156]^{* *}}\end{array}$ & $\begin{array}{l}3.4145 \\
{[2.6803]^{* *}}\end{array}$ & $\begin{array}{l}5.1826 \\
{[1.9104]^{\text {***}}}\end{array}$ & $\begin{array}{c}-7.2319 \\
{[-2.5906]^{* *}}\end{array}$ & $\begin{array}{c}0.8879 \\
{[14.9814]^{*}}\end{array}$ \\
\hline \multirow[t]{6}{*}{ Terengganu } & $\dot{\varepsilon}_{\mathrm{t}-1}$ & $\begin{array}{c}0.01131 \\
{[2.0879]^{* *}}\end{array}$ & $\begin{array}{c}0.0043 \\
{[0.8442]}\end{array}$ & $\begin{array}{c}-0.0044 \\
{[-0.2936]}\end{array}$ & $\begin{array}{c}-0.0257 \\
{[-5.2213]^{*}}\end{array}$ & $\begin{array}{c}0.0006 \\
{[1.7925]^{* * * *}}\end{array}$ \\
\hline & $\Delta \mathrm{G}_{\mathrm{t}-1}$ & $\begin{array}{c}0.2506 \\
{[1.1435]}\end{array}$ & $\begin{array}{c}-0.2931 \\
{[-1.6616]}\end{array}$ & $\begin{array}{c}0.3544 \\
{[0.6781]}\end{array}$ & $\begin{array}{c}0.5313 \\
{[3.1004]^{*}}\end{array}$ & $\begin{array}{c}-0.0099 \\
{[-0.8815]}\end{array}$ \\
\hline & $\Delta \mathrm{Y}_{\mathrm{t}-1}$ & $\begin{array}{c}0.1825 \\
{[0.8126]}\end{array}$ & $\begin{array}{c}0.0893 \\
{[0.4938]}\end{array}$ & $\begin{array}{c}0.3425 \\
{[0.6393]}\end{array}$ & $\begin{array}{c}0.0891 \\
{[0.5072]}\end{array}$ & $\begin{array}{c}0.0289 \\
{[2.5042]^{* *}}\end{array}$ \\
\hline & $\Delta \mathrm{HC}_{\mathrm{t}-1}$ & $\begin{array}{c}0.0381 \\
{[0.3415]}\end{array}$ & $\begin{array}{l}0.1884 \\
{[2.0981]^{* *}}\end{array}$ & $\begin{array}{c}-0.0417 \\
{[-0.1566]}\end{array}$ & $\begin{array}{c}-0.3716 \\
{[-4.2589]^{*}}\end{array}$ & $\begin{array}{c}0.0029 \\
{[0.5134]}\end{array}$ \\
\hline & $\Delta \mathrm{IF}_{\mathrm{t}-1}$ & $\begin{array}{c}0.0499 \\
{[0.2669]}\end{array}$ & $\begin{array}{c}-0.0013 \\
{[-0.0089]}\end{array}$ & $\begin{array}{c}-0.0096 \\
{[-0.0215]}\end{array}$ & $\begin{array}{c}0.1891 \\
{[1.2939]}\end{array}$ & $\begin{array}{c}0.0023 \\
{[0.2400]}\end{array}$ \\
\hline & $\Delta \mathrm{POP}_{\mathrm{t}-1}$ & $\begin{array}{c}0.8067 \\
{[0.3977]}\end{array}$ & $\begin{array}{l}3.5157 \\
{[2.1535]^{* *}}\end{array}$ & $\begin{array}{c}1.5124 \\
{[0.3126]}\end{array}$ & $\begin{array}{c}1.9303 \\
{[1.2168]}\end{array}$ & $\begin{array}{c}0.7416 \\
{[7.1179]^{*}}\end{array}$ \\
\hline \multirow[t]{6}{*}{ Pahang } & $\dot{\varepsilon}_{t-1}$ & $\begin{array}{l}-0.1422 \\
{[-1.9082]^{* * *}}\end{array}$ & $\begin{array}{c}0.0423 \\
{[1.7284]^{* * * *}}\end{array}$ & $\begin{array}{c}0.0420 \\
{[1.6502]}\end{array}$ & $\begin{array}{c}0.2268 \\
{[2.6521]^{* *}}\end{array}$ & $\begin{array}{c}0.0147 \\
{[2.9505]^{*}}\end{array}$ \\
\hline & $\Delta \mathrm{G}_{\mathrm{t}-1}$ & $\begin{array}{c}-0.4431 \\
{[-1.5224]}\end{array}$ & $\begin{array}{c}-0.3328 \\
{[-3.4819]^{*}}\end{array}$ & $\begin{array}{c}-0.0031 \\
{[-0.0314]}\end{array}$ & $\begin{array}{c}0.0948 \\
{[0.2838]}\end{array}$ & $\begin{array}{c}-0.0206 \\
{[-1.0597]}\end{array}$ \\
\hline & $\Delta \mathrm{Y}_{\mathrm{t}-1}$ & $\begin{array}{c}-0.0814 \\
{[-0.1219]}\end{array}$ & $\begin{array}{c}0.0868 \\
{[0.3956]}\end{array}$ & $\begin{array}{c}-0.1324 \\
{[-0.5804]}\end{array}$ & $\begin{array}{c}0.5820 \\
{[0.7597]}\end{array}$ & $\begin{array}{c}-0.0232 \\
{[-0.5199]}\end{array}$ \\
\hline & $\Delta \mathrm{HC}_{\mathrm{t}-1}$ & $\begin{array}{l}1.1472 \\
{[1.8204]^{* * *}}\end{array}$ & $\begin{array}{l}0.3798 \\
{[1.8349]^{* * * *}}\end{array}$ & $\begin{array}{c}-0.2345 \\
{[-1.0895]}\end{array}$ & $\begin{array}{l}-1.3627 \\
{[-1.8849]^{* * *}}\end{array}$ & $\begin{array}{c}0.0386 \\
{[0.9167]}\end{array}$ \\
\hline & $\Delta \mathrm{IF}_{\mathrm{t}-1}$ & $\begin{array}{c}-0.0679 \\
{[-0.2779]}\end{array}$ & $\begin{array}{c}-0.2829 \\
{[-3.5219]^{*}}\end{array}$ & $\begin{array}{c}-0.0526 \\
{[-0.6297]}\end{array}$ & $\begin{array}{c}-0.2939 \\
{[-1.0475]}\end{array}$ & $\begin{array}{c}-0.0023 \\
{[-0.1426]}\end{array}$ \\
\hline & $\Delta \mathrm{POP}_{\mathrm{t}-1}$ & $\begin{array}{l}8.6059 \\
{[2.1784]^{* *}}\end{array}$ & $\begin{array}{c}0.6972 \\
{[0.5374]}\end{array}$ & $\begin{array}{c}-0.8426 \\
{[-0.6244]}\end{array}$ & $\begin{array}{l}-12.1603 \\
{[-2.6829]^{* *}}\end{array}$ & $\begin{array}{c}0.2767 \\
{[1.0478]}\end{array}$ \\
\hline
\end{tabular}

(sambungan) 
IJMS 19 (2), 125-150 (2012)

\begin{tabular}{|c|c|c|c|c|c|c|}
\hline \multirow[t]{2}{*}{ Negeri } & \multirow{2}{*}{$\begin{array}{l}\text { Pemboleh } \\
\text { ubah bebas }\end{array}$} & \multicolumn{5}{|c|}{ Pemboleh ubah bersandar } \\
\hline & & $\Delta \mathrm{G}$ & $\Delta \mathrm{Y}$ & $\Delta \mathrm{HC}$ & $\Delta \mathrm{IF}$ & $\triangle \mathrm{POP}$ \\
\hline \multirow[t]{6}{*}{ Johor } & $\dot{\varepsilon}_{\mathrm{t}-1}$ & $\begin{array}{l}-0.0631 \\
{[-1.6878]^{* * *}}\end{array}$ & $\begin{array}{c}-0.0237 \\
{[-1.0776]}\end{array}$ & $\begin{array}{c}-0.0301 \\
{[-1.3896]}\end{array}$ & $\begin{array}{c}-0.0803 \\
{[-2.1304]^{* *}}\end{array}$ & $\begin{array}{c}-0.0018 \\
{[-2.4901]^{* *}}\end{array}$ \\
\hline & $\Delta \mathrm{G}_{\mathrm{t}-1}$ & $\begin{array}{c}0.0256 \\
{[0.1663]}\end{array}$ & $\begin{array}{c}-0.0644 \\
{[-0.7118]}\end{array}$ & $\begin{array}{c}-0.0675 \\
{[-0.7563]}\end{array}$ & $\begin{array}{c}-0.2102 \\
{[-1.3541]}\end{array}$ & $\begin{array}{c}0.0086 \\
{[2.9489]^{*}}\end{array}$ \\
\hline & $\Delta \mathrm{Y}_{\mathrm{t}-1}$ & $\begin{array}{c}-0.1238 \\
{[-0.3475]}\end{array}$ & $\begin{array}{c}-0.0633 \\
{[-0.3025]}\end{array}$ & $\begin{array}{c}-0.1177 \\
{[-0.5702]}\end{array}$ & $\begin{array}{c}-0.8059 \\
{[-2.2462]^{* *}}\end{array}$ & $\begin{array}{c}0.0066 \\
{[0.9744]}\end{array}$ \\
\hline & $\Delta \mathrm{HC}_{\mathrm{t}-1}$ & $\begin{array}{l}0.8444 \\
{[2.6796]^{* *}}\end{array}$ & $\begin{array}{c}-0.2065 \\
{[-1.1158]}\end{array}$ & $\begin{array}{c}-0.0412 \\
{[-0.2257]}\end{array}$ & $\begin{array}{c}-0.1219 \\
{[-0.3840]}\end{array}$ & $\begin{array}{c}0.0016 \\
{[0.2623]}\end{array}$ \\
\hline & $\Delta \mathrm{IF}_{\mathrm{t}-1}$ & $\begin{array}{c}-0.0951 \\
{[-0.4484]}\end{array}$ & $\begin{array}{c}0.1677 \\
{[1.3464]}\end{array}$ & $\begin{array}{c}-0.1745 \\
{[-1.4199]}\end{array}$ & $\begin{array}{c}-0.5722 \\
{[-2.6786]^{* *}}\end{array}$ & $\begin{array}{c}-0.0014 \\
{[-0.3439]}\end{array}$ \\
\hline & $\Delta \mathrm{POP}_{\mathrm{t}-1}$ & $\begin{array}{l}-23.3889 \\
{[-1.7387]^{* * *}}\end{array}$ & $\begin{array}{c}-4.3499 \\
{[-0.5508]}\end{array}$ & $\begin{array}{c}-8.3700 \\
{[-1.0740]}\end{array}$ & $\begin{array}{l}-26.9217 \\
{[-1.9871]^{* * *}}\end{array}$ & $\begin{array}{c}0.2498 \\
{[0.9758]}\end{array}$ \\
\hline \multirow[t]{6}{*}{ Melaka } & $\dot{\varepsilon}_{\mathrm{t}-1}$ & $\begin{array}{c}0.2095 \\
{[3.5554]^{*}}\end{array}$ & $\begin{array}{c}0.0500 \\
{[2.2798]^{* *}}\end{array}$ & $\begin{array}{l}0.0519 \\
{[2.2345]^{* *}}\end{array}$ & $\begin{array}{l}-0.1373 \\
{[-2.0838]^{* *}}\end{array}$ & $\begin{array}{c}0.0116 \\
{[2.9959]^{*}}\end{array}$ \\
\hline & $\Delta \mathrm{G}_{\mathrm{t}-1}$ & $\begin{array}{c}-0.6611 \\
{[-1.6175]}\end{array}$ & $\begin{array}{c}0.2255 \\
{[1.4812]}\end{array}$ & $\begin{array}{c}-0.1801 \\
{[-1.1163]}\end{array}$ & $\begin{array}{c}0.3979 \\
{[0.8707]}\end{array}$ & $\begin{array}{c}-0.0440 \\
{[-1.6445]}\end{array}$ \\
\hline & $\Delta \mathrm{Y}_{\mathrm{t}-1}$ & $\begin{array}{l}-1.0723 \\
{[-2.0157]^{* *}}\end{array}$ & $\begin{array}{c}-0.0727 \\
{[-0.3668]}\end{array}$ & $\begin{array}{c}0.0338 \\
{[0.1609]}\end{array}$ & $\begin{array}{l}1.0109 \\
{[1.6993]^{* * *}}\end{array}$ & $\begin{array}{c}-0.0184 \\
{[-0.5273]}\end{array}$ \\
\hline & $\Delta \mathrm{HC}_{\mathrm{t}-1}$ & $\begin{array}{c}-0.1019 \\
{[-0.2435]}\end{array}$ & $\begin{array}{c}-0.1752 \\
{[-1.1245]}\end{array}$ & $\begin{array}{c}-0.1195 \\
{[-0.7240]}\end{array}$ & $\begin{array}{c}0.0460 \\
{[0.0984]}\end{array}$ & $\begin{array}{c}0.0115 \\
{[0.4206]}\end{array}$ \\
\hline & $\Delta \mathrm{IF}_{\mathrm{t}-1}$ & $\begin{array}{c}-0.5524 \\
{[-1.4218]}\end{array}$ & $\begin{array}{c}0.1593 \\
{[1.1005]}\end{array}$ & $\begin{array}{c}-0.1285 \\
{[-0.8382]}\end{array}$ & $\begin{array}{c}0.1281 \\
{[0.2948]}\end{array}$ & $\begin{array}{c}-0.0324 \\
{[-1.2714]}\end{array}$ \\
\hline & $\Delta \mathrm{POP}_{\mathrm{t}-1}$ & $\begin{array}{l}-7.7366 \\
{[-2.4274]^{* *}}\end{array}$ & $\begin{array}{c}0.3699 \\
{[0.3116]}\end{array}$ & $\begin{array}{c}0.4308 \\
{[0.3425]}\end{array}$ & $\begin{array}{l}6.5666 \\
{[1.8423]^{* * *}}\end{array}$ & $\begin{array}{c}0.0103 \\
{[0.0494]}\end{array}$ \\
\hline \multirow[t]{6}{*}{ Perak } & $\dot{\varepsilon}_{\mathrm{t}-1}$ & $\begin{array}{c}0.0037 \\
{[0.2610]}\end{array}$ & $\begin{array}{c}0.0265 \\
{[2.5543]^{* *}}\end{array}$ & $\begin{array}{c}0.0341 \\
{[6.3477]^{*}}\end{array}$ & $\begin{array}{c}-0.0127 \\
{[-1.0255]}\end{array}$ & $\begin{array}{c}0.0023 \\
{[1.1407]}\end{array}$ \\
\hline & $\Delta \mathrm{G}_{\mathrm{t}-1}$ & $\begin{array}{c}0.0940 \\
{[0.4062]}\end{array}$ & $\begin{array}{c}0.3366 \\
{[1.9598]^{* * *}}\end{array}$ & $\begin{array}{c}0.2972 \\
{[1.9221]^{* * *}}\end{array}$ & $\begin{array}{c}-0.3017 \\
{[-1.4728]}\end{array}$ & $\begin{array}{c}-0.0912 \\
{[-2.7247]^{*}}\end{array}$ \\
\hline & $\Delta \mathrm{Y}_{\mathrm{t}-1}$ & $\begin{array}{c}0.2442 \\
{[0.7512]}\end{array}$ & $\begin{array}{c}-0.2629 \\
{[-1.0903]}\end{array}$ & $\begin{array}{c}-0.1999 \\
{[-0.9207]}\end{array}$ & $\begin{array}{c}0.4348 \\
{[1.5115]}\end{array}$ & $\begin{array}{c}0.0583 \\
{[1.2402]}\end{array}$ \\
\hline & $\Delta \mathrm{HC}_{\mathrm{t}-1}$ & $\begin{array}{c}0.0695 \\
{[0.3375]}\end{array}$ & $\begin{array}{c}-0.3363 \\
{[-2.2019]^{* *}}\end{array}$ & $\begin{array}{c}-0.0446 \\
{[-0.3247]}\end{array}$ & $\begin{array}{c}-0.0301 \\
{[-0.1652]}\end{array}$ & $\begin{array}{l}0.0759 \\
{[2.5517]^{* *}}\end{array}$ \\
\hline & $\Delta \mathrm{IF}_{\mathrm{t}-1}$ & $\begin{array}{c}0.3755 \\
{[1.6211]}\end{array}$ & $\begin{array}{l}0.3246 \\
{[1.8884]^{* * *}}\end{array}$ & $\begin{array}{c}0.4350 \\
{[2.8113]^{*}}\end{array}$ & $\begin{array}{l}-0.5266 \\
{[-2.5684]^{* *}}\end{array}$ & $\begin{array}{c}-0.0493 \\
{[-1.4706]}\end{array}$ \\
\hline & $\Delta \mathrm{POP}_{\mathrm{t}-1}$ & $\begin{array}{c}0.0788 \\
{[0.0739]}\end{array}$ & $\begin{array}{c}0.4321 \\
{[0.5466]}\end{array}$ & $\begin{array}{c}-0.4488 \\
{[-0.6306]}\end{array}$ & $\begin{array}{c}1.1531 \\
{[1.2228]}\end{array}$ & $\begin{array}{c}0.1128 \\
{[0.7315]}\end{array}$ \\
\hline \multirow[t]{6}{*}{$\begin{array}{l}\text { Pulau } \\
\text { Pinang }\end{array}$} & $\dot{\varepsilon}_{\mathrm{t}-1}$ & $\begin{array}{c}-0.3278 \\
{[-4.2067]^{*}}\end{array}$ & $\begin{array}{c}0.0372 \\
{[0.9216]}\end{array}$ & $\begin{array}{c}0.0194 \\
{[0.3684]}\end{array}$ & $\begin{array}{c}0.3753 \\
{[4.6149]^{*}}\end{array}$ & $\begin{array}{c}-0.0015 \\
{[-0.9331]}\end{array}$ \\
\hline & $\Delta \mathrm{G}_{\mathrm{t}-1}$ & $\begin{array}{c}-0.7261 \\
{[-1.6324]}\end{array}$ & $\begin{array}{c}-0.0122 \\
{[-0.0529]}\end{array}$ & $\begin{array}{c}-0.4185 \\
{[-1.3941]}\end{array}$ & $\begin{array}{c}0.3022 \\
{[0.6509]}\end{array}$ & $\begin{array}{c}-0.0090 \\
{[-1.0074]}\end{array}$ \\
\hline & $\Delta \mathrm{Y}_{\mathrm{t}-1}$ & $\begin{array}{l}-0.9378 \\
{[-2.2385]^{* *}}\end{array}$ & $\begin{array}{c}0.0608 \\
{[0.2799]}\end{array}$ & $\begin{array}{c}0.5132 \\
{[1.8151]^{* * *}}\end{array}$ & $\begin{array}{c}1.4340 \\
{[3.2799]^{*}}\end{array}$ & $\begin{array}{c}-0.0055 \\
{[-0.6486]}\end{array}$ \\
\hline & $\Delta \mathrm{HC}_{\mathrm{t}-1}$ & $\begin{array}{c}-0.1267 \\
{[-0.3998]}\end{array}$ & $\begin{array}{c}0.0164 \\
{[0.0999]}\end{array}$ & $\begin{array}{c}-0.0019 \\
{[-0.0088]}\end{array}$ & $\begin{array}{c}0.2286 \\
{[0.6911]}\end{array}$ & $\begin{array}{c}0.0016 \\
{[0.2483]}\end{array}$ \\
\hline & $\Delta \mathrm{IF}_{\mathrm{t}-1}$ & $\begin{array}{c}-0.4806 \\
{[-1.2669]}\end{array}$ & $\begin{array}{c}0.0171 \\
{[0.0868]}\end{array}$ & $\begin{array}{c}-0.2369 \\
{[-0.9252]}\end{array}$ & $\begin{array}{c}0.0736 \\
{[0.1859]}\end{array}$ & $\begin{array}{c}-0.0089 \\
{[-1.1623]}\end{array}$ \\
\hline & $\Delta \mathrm{POP}_{\mathrm{t}-1}$ & $\begin{array}{c}-2.5289 \\
{[-0.2843]}\end{array}$ & $\begin{array}{c}-0.7093 \\
{[-0.1538]}\end{array}$ & $\begin{array}{c}-3.1927 \\
{[-0.5318]}\end{array}$ & $\begin{array}{c}4.4280 \\
{[0.4769]}\end{array}$ & $\begin{array}{c}0.2669 \\
{[1.4919]}\end{array}$ \\
\hline
\end{tabular}


Nota. Model ini dijana dengan pintasan. Lat optimum adalah satu yang ditentukan menerusi kaedah Akaike Info Criterion (AIC) dan sama seperti dalam ujian kointegrasi Johansen. Nilai dalam [ ] merujuk kepada statistik-t. *signifikan pada aras keertian 1\%. ${ }^{* *}$ signifikan pada aras keertian $5 \% .{ }^{* * *}$ signifikan pada aras keertian $10 \%$.

Walaupun begitu, keputusan di Kedah mencerminkan belanja awam dan imbangan fiskal mempunyai hubungan dua hala dan turut dipengaruh oleh pemboleh ubah lain dalam jangka panjang. Manakala, dalam jangka pendek, terbukti hasil cukai dan belanja awam saling mempengaruhi. Keputusan ini sama seperti hubungan dua hala antara populasi dan output negeri. Namun, belanja awam juga terpengaruh dengan perubahan output dan imbangan fiskal. Selain itu, hasil cukai dominan terpengaruh oleh output dan populasi, imbangan fiskal pula dipengaruh hasil cukai dan belanja awam mempengaruhi perubahan populasi. Bagi kes Kelantan pula, dapatan menunjukkan belanja awam, output negeri, hasil cukai dan populasi merupakan penyebab Granger jangka panjang kepada imbangan fiskal. Tetapi dalam jangka pendek, wujud tiga bentuk hubungan dua hala, iaitu antara imbangan fiskal dan belanja awam, populasi dan output, serta populasi dan hasil cukai. Dalam masa yang sama, belanja awam turut dipengaruh populasi, imbangan fiskal memberi kesan kepada output dan populasi pula mempengaruhi perubahan imbangan fiskal.

Analisis keputusan terhadap Terengganu pula mendapati belanja awam, imbangan fiskal dan populasi mempunyai hubungan dua hala jangka panjang. Sebaliknya, hanya populasi dan output sahaja yang berhubungan dua hala dalam jangka pendek. Manakala hasil cukai dilihat menjadi penyebab Granger jangka pendek kepada output dan imbangan fiskal. Begitu juga dengan belanja awam yang turut menjadi penerang kepada perubahan imbangan fiskal. Seterusnya bagi Pahang, wujud hubungan dua hala antara belanja awam, output, imbangan fiskal dan populasi dalam jangka panjang. Ini bererti wujud hipotesis Wagner serta Keynes di Pahang dalam jangka panjang. Namun, keputusan dalam jangka pendek hanya dapat membuktikan kewujudan hubungan sehala antara pemboleh ubah; belanja awam dipengaruh oleh hasil cukai dan populasi, output negeri terpengaruh oleh perubahan belanja awam, hasil cukai dan imbangan fiskal, serta hasil cukai dan populasi adalah penyebab Granger kepada imbangan fiskal. 
Seperti keputusan di Terengganu sebelum ini, analisis bagi Johor juga menunjukkan belanja awam, imbangan fiskal dan populasi mempunyai hubungan dua hala dalam jangka panjang tetapi hanya belanja awam dan populasi berhubungan dua hala dalam jangka pendek. Hasil cukai juga didapati menjadi penyebab Granger jangka pendek kepada belanja awam, sedangkan perubahan imbangan fiskal dipengaruh oleh perubahan dalam output negeri dan populasi. Namun, dapatan bagi Melaka pula unik apabila kesemua pemboleh ubah saling mempengaruhi dalam jangka panjang yang secara tidak langsung menunjukkan wujud hipotesis Wagner dan Keynes di negeri ini dalam jangka panjang. Sebaliknya, hanya output dan populasi menjadi penyebab Granger jangka pendek kepada belanja awam dan imbangan fiskal. Di Perak pula, output dan hasil cukai mempunyai hubungan dua hala dalam jangka panjang. Manakala dalam jangka pendek, belanja awam, hasil cukai dan imbangan fiskal mempengaruhi output, sebaliknya, hasil cukai hanya dipengaruh oleh belanja awam dan imbangan fiskal. Di samping itu, belanja awam dan hasil cukai juga menjadi penyebab Granger jangka pendek kepada populasi. Seterusnya, bagi kes Pulau Pinang, dalam jangka panjang wujud hubungan dua hala antara belanja awam dan imbangan fiskal, sedangkan dalam jangka pendek, hanya output signifikan mempengaruhi belanja awam, hasil cukai dan imbangan fiskal. Secara keseluruhannya, keputusan ujian penyebab Granger versi VECM adalah lebih stabil di Melaka dan Pahang memandangkan hampir kesemua pemboleh ubah saling mempengaruhi dalam jangka panjang.

Di Selangor, oleh kerana tidak wujud hubungan jangka panjang (kointegrasi) dalam kalangan pemboleh ubah, maka ujian sebab-menyebab perlulah dilakukan tanpa memasukkan pemboleh ubah pembetulan ralat tertangguh (eror correction term) dalam model VAR. Jadual 4 meringkaskan keputusan ujian sebab-menyebab di Selangor, yang mana ia menunjukkan populasi signifikan mempengaruhi belanja awam dan hasil cukai, manakala hasil cukai menjadi penyebab Granger jangka pendek kepada imbangan fiskal. 
IJMS 19 (2), 125-150 (2012)

Jadual 4

Keputusan Ujian VAR Negeri Selangor

\begin{tabular}{|c|c|c|c|c|c|c|}
\hline \multirow[t]{2}{*}{ Negeri } & \multirow{2}{*}{$\begin{array}{l}\text { Pemboleh } \\
\text { ubah bebas }\end{array}$} & \multicolumn{5}{|c|}{ Pemboleh ubah bersandar } \\
\hline & & $\Delta G$ & $\Delta \mathrm{Y}$ & $\Delta \mathrm{HC}$ & $\Delta \mathrm{IF}$ & $\triangle \mathrm{POP}$ \\
\hline \multirow[t]{9}{*}{ Selangor } & $\Delta \mathrm{G}_{\mathrm{t}-1}$ & $\begin{array}{r}0.0204 \\
{[0.1052]}\end{array}$ & $\begin{array}{r}0.2805 \\
{[0.7339]}\end{array}$ & $\begin{array}{r}-0.4578 \\
{[-1.6687]}\end{array}$ & $\begin{array}{r}-0.3691 \\
{[-1.5981]}\end{array}$ & $\begin{array}{r}0.0216 \\
{[0.3454]}\end{array}$ \\
\hline & $\Delta \mathrm{Y}_{\mathrm{t}-1}$ & $\begin{array}{r}0.0136 \\
{[0.1526]}\end{array}$ & $\begin{array}{r}-0.1752 \\
{[-0.9955]}\end{array}$ & $\begin{array}{r}0.0848 \\
{[0.6713]}\end{array}$ & $\begin{array}{r}0.0307 \\
{[0.2885]}\end{array}$ & $\begin{array}{r}0.0120 \\
{[0.4166]}\end{array}$ \\
\hline & $\Delta \mathrm{HC}_{\mathrm{t}-1}$ & $\begin{array}{r}0.1008 \\
{[0.7473]}\end{array}$ & $\begin{array}{r}-0.0758 \\
{[-0.2849]}\end{array}$ & $\begin{array}{r}-0.0883 \\
{[-0.4628]}\end{array}$ & $\begin{array}{r}0.3885 \\
{[2.4182]^{*}}\end{array}$ & $\begin{array}{r}0.0075 \\
{[0.1724]}\end{array}$ \\
\hline & $\Delta \mathrm{IF}_{\mathrm{t}-1}$ & $\begin{array}{r}0.1584 \\
{[1.1491]}\end{array}$ & $\begin{array}{r}0.1013 \\
{[0.3730]}\end{array}$ & $\begin{array}{r}0.2298 \\
{[1.1787]}\end{array}$ & $\begin{array}{r}-0.3255 \\
{[-1.9828]^{*}}\end{array}$ & $\begin{array}{r}0.0481 \\
{[1.0801]}\end{array}$ \\
\hline & $\Delta \mathrm{POP}_{\mathrm{t}-1}$ & $\begin{array}{r}-1.2245 \\
{[-1.7819]^{*}}\end{array}$ & $\begin{array}{r}0.7058 \\
{[0.5212]}\end{array}$ & $\begin{array}{r}-1.9585 \\
{[-2.0147]^{*}}\end{array}$ & $\begin{array}{r}0.0702 \\
{[0.0858]}\end{array}$ & $\begin{array}{r}0.1214 \\
{[0.5469]}\end{array}$ \\
\hline & C & $\begin{array}{r}0.1129 \\
{[2.6062]^{*}}\end{array}$ & $\begin{array}{r}-0.0012 \\
{[-0.0145]}\end{array}$ & $\begin{array}{r}0.1824 \\
{[2.9766]^{*}}\end{array}$ & $\begin{array}{r}-0.0128 \\
{[-0.2475]}\end{array}$ & $\begin{array}{r}0.0237 \\
{[1.6978]^{*}}\end{array}$ \\
\hline & $\mathrm{R}^{2}$ & 0.1439 & 0.0478 & 0.3556 & 0.3802 & 0.0517 \\
\hline & $\mathrm{R}^{2}$ terselaras & 0.0058 & -0.1058 & 0.2516 & 0.2802 & -0.1013 \\
\hline & Statistik-F & 1.0418 & 0.3110 & 3.4207 & 3.8030 & 0.3379 \\
\hline
\end{tabular}

Nota. Nilai dalam [ ] merujuk kepada statistik-t. *signifikan pada aras keertian 5\%. Lat optimum bagi ujian ini adalah satu yang dijana menerusi kaedah Akaike Info Criterion (AIC).

\section{Kesimpulan}

Kajian ini bertujuan untuk mengkaji hubungan antara pemboleh ubah perbelanjaan kerajaan dengan pertumbuhan ekonomi dengan menggunakan data pada peringkat kerajaan negeri di Semenanjung Malaysia. Ujian kointegrasi Johansen diaplikasikan untuk melihat hubungan jangka panjang dalam kalangan pemboleh ubah, manakala ujian model vektor pembetulan ralat (VECM) pula digunakan untuk melihat arah sebab-menyebab dalam jangka panjang dan jangka pendek.

Dapatan kajian menunjukkan terdapat beberapa bentuk hubungan antara output dengan belanja awam dalam jangka panjang dan jangka pendek. Pertama, tidak wujud hubungan jangka panjang antara output negeri dengan belanja awam di Selangor. Kedua, di Pahang dan Melaka wujud hubungan dua hala dalam jangka panjang 
antara output negeri dan belanja awam. Dapatan ini mengesahkan hipotesis Wagner dan Keynes di kedua-dua negeri tersebut. Ketiga, dalam jangka pendek, wujud hipotesis Wagner di Negeri Sembilan, Kedah, Melaka dan Pulau Pinang. Manakala, hipotesis Keynes berjaya disahkan di Pahang dan Perak dalam jangka pendek. Keputusan yang pelbagai ini disebabkan oleh dasar pengurusan serta pembangunan yang berbeza antara negeri yang menyebabkan peruntukan terhadap perbelanjaan awam yang berbeza.

Selain itu, keputusan kajian yang menunjukkan pertumbuhan ekonomi kurang dipengaruh oleh perbelanjaan awam di kebanyakan kerajaan negeri memberikan dua implikasi penting kepada strategi pembangunan ekonomi negeri. Pertama, kerajaan negeri perlulah menggalakkan penglibatan yang aktif daripada sektor swasta, yakni daripada peniaga kecil hinggalah kepada konglomerat ternama untuk memacu pertumbuhan ekonomi negeri. Strategi pertumbuhan ekonomi diterajui oleh sektor swasta (private sector led growth) boleh dilakukan oleh pihak kerajaan negeri dengan menyediakan keperluan prasarana yang lebih baik dan moden, di samping insentif fiskal dan kewangan yang lebih kompetitif untuk menarik pelaburan domestik dan asing. Kedua, cerapan terhadap komponen belanja awam negeri menunjukkan bahawa kerajaan negeri membuat perbelanjaan yang lebih besar terhadap perbelanjaan mengurus berbanding dengan perbelanjaan pembangunan. Seperti yang diketahui umum, belanja mengurus adalah merupakan belanja yang kurang produktif, lantas ia tidak mampu merangsang pertumbuhan ekonomi negeri dalam jangka panjang. Maka, untuk meningkatkan kefisienan komponen perbelanjaan awam yang berbeza terhadap output, maka pembuat dasar pada peringkat kerajaan negeri perlukan peka kepada kitaran perniagaan sebelum membuat keputusan perbelanjaan. Percaturan terhadap komponen belanja awam yang bijak ini sudah pasti akan dapat mengurangkan lagi defisit dan hutang fiskal, serta membantu mengukuhkan lagi kewangan fiskal kerajaan negeri. Seperkara lagi berkaitan dengan pengukuhan fiskal, disebabkan dapatan kajian ini membuktikan HC juga mempengaruhi peruntukan belanja awam, output dan imbangan fiskal, maka setiap kerajaan negeri harus berusaha mengurangkan jurang di antara 'tax effort' dengan 'tax capacity' menerusi pengurangan jumlah cukai tertunggak tahunan. Secara langsung, apabila kerajaan negeri cekap dalam kutipan hasil cukai dan hasil bukan cukai, maka kerajaan negeri tidak lagi perlu terlalu bergantung kepada bantuan (geran) daripada kerajaan pusat serta mengelak daripada berlakunya penangguhan projek pembangunan negeri akibat kekurangan dana pembiayaan. 


\section{Rujukan}

Akitoby, B., Clements, B., Gupta, S., \& Inchauste, G. (2006). Public spending, voracity, and Wagner's Law in developing countries. European Journal of Political Economy, 22(4), 908-924.

Al-Faris, A. F. (2002). Public expenditure and economic growth in the gulf cooperation council countries. Applied Economics, 34, 1187-1193.

Aschauer, D. A. (1989). Is public expenditure productive? Journal of Monetary Economics, 23, 117-200.

Barro, R. J. (1981). Output effects of government purchases. Journal of Political Economy, 89, 1086-1121.

Barro, R. J. (1987). Government spending, interest rates, prices and budget deficits in the United Kingdom 1701-1918. Journal of Monetary Economics, 20, 221-247.

Barro, R. J. (1990). Government spending in a simple model of endogenous growth. Journal of Political Economy, 98, 103-125.

Barro, R. J. (1991). Economic growth in a cross-section of countries. Quarterly Jounal of Economics, 106, 407-444.

Dayang-Affizzah, A. M., Habibullah, M. S., \& Azman-Saini, W. N. W. (2006). Expenditures and revenues: Testing for causality in Sabah local government finances. International Journal of Economics and Management, 1(1), 1-23.

De Mello, L. R. J. (2002). Public finance, government spending and economic growth: The case of local governments in Brazil. Applied Economics, 34, 1871-1883.

Devarajan, S., Swaroop, V., \& Zou, H. (1996). The composition of public expenditure and economic growth. Journal of Monetary Economics, 37, 313-344.

Evans, P., \& Karras, G. (1994). Are government activities productive? Evidence from a panel of US states. Review of Economics and Statistics, 76, 1-11.

Fatimah, S., Zarinah, Y., Saad, M. S., \& Ahmad Farid, O. (2010). Foreign investment, government expenditure, and economic growth in Malaysia. International Journal of Management Studies, 17(1), 1-18.

Folster, S., \& Henrekson, M. (2001). Growth effects of government expenditure and taxation in rich countries. European Economic Review, 45, 1501-1520.

Ghani, J. A., Habibullah, M. S., Azali, M., \& Azman-Saini, W.N.W. (2005). Is Wagner or Keynes right? Testing the government expenditure and economic growth nexus in Malaysia. The ICFAI Journal of Public Finance, 3(4), 35-42. 
Glass, A. (2009). Government expenditure on public order and safety, economic growth and private investment: Empirical evidence from the United States. International Review of Law and Economics, 29, 29-37.

Granger, C. W. J. (1969). Investigating causal relations by econometric models and cross-spectral methods. Econometrica, July, 424-438.

Grossman, G. M., \& Helpman, E. (1991). Innovation and growth in the global economy. Cambridge: The MIT Press.

Habibullah, M. S., \& Dayang-Affizzah, A. M. (2008). The tax-spend debate: Time series evidence from Sarawak municipals, 19752003. The ICFAI Journal of Public Finance, 6(1), 52-65.

Henrekson, M. (1993). Wagner's Law: A spurious relationship. Public Finance, 48(3), 406-415.

Johansen, S., \& Juselius, K. (1990). Maximum likelihood estimation and inferences on cointegration with application to the demand for money. Oxford Bulletin of Economics and Statistics, 52, 169-210.

Kolluri, B. R., Panik, M. J., \& Wahab, M. S. (2000). Government expenditure and economic growth: Evidence from G7 countries. Applied Economics, 32, 1059-1068.

Mattos, E., \& Rocha, F. (2008). Inequality and size of government: Evidence from Brazilian states. Journal of Economic Studies, 35(4), 333-351.

Norain, M. A., Md Zyadi, M. T., \& Wook, E. (2010). Komposisi perbelanjaan kerajaan dan pertumbuhan ekonomi: Kajian empirikal di Malaysia. Jurnal Kemanusiaan, 15, 23-45.

Osterwald-Lenum, M. (1992). A note with quantiles of the asymptotic distribution of the maximum likelihood cointegration rank test statistics. Oxford Bulletin of Economics and Statistics, 54, 461-471.

Rao, V. V. B. (1989). Government size and economic growth: A new framework and some evidence from cross-section and time-series data: Comment. The American Economic Review, 79(1), 272-280.

Raurich, X. (2001). Indeterminacy and government spending in a two-sector model of endogenous growth. Review of Economic Dynamics, 4, 210-229.

Said, S. E., \& Dickey, D. A. (1984). Testing for unit roots in autoregressive moving average models of unknown order. Biometrika, 71, 599-607.

Sinha, D. (1998). Government expenditure and economic growth in Malaysia. Journal of Economic Development, 23(2), 71-80.

Tanzi, V., \& Zee, H. H. (1996). Fiscal policy and long-run growth. IMF Working Paper No. WP/96/119.

Wagner, R. E. (1958). Three extracts on public finance. In. R. A. Musgrave \& Peacock, A. T (Eds.), Classics in the theory of public finance. London: Macmillan. 
IJMS 19 (2), 125-150 (2012)

Wahab, M. (2004). Economic growth and government expenditure: Evidence from a new test specification. Applied Economics, 36, 2125-2135.

Wahab, M. (2010). Asymmetric output growth effects of government spending: Cross-sectional and panel data evidence. International Review of Economics and Finance, 24(4), 574-590. 